\title{
Genesis of Late Cretaceous-Paleogene Granitoids with Contrasting Chemical Trends in the Chubu District, Central Japan
}

\author{
Shunso IsHiHARA ${ }^{1}$ and Chengyu $\mathrm{W}_{\mathrm{U}^{2}}$
}

\begin{abstract}
Shunso IshiHara and Chengyu Wu (2001) Genesis of late Cretaceous-Paleogene granitoids with contrasting chemical trends in the Chubu District, central Japan. Bull. Geol. Surv. Japan, vol. 52 (10), p.471-491, 9 figs., 1 table, 3 appendices.
\end{abstract}

\begin{abstract}
Late Cretaceous to Paleogene rhyolites (11 samples) and granitoids (Shirakawa 29, Toki 7, Naegi 9, Ryoke 10; total 55 samples), which have high intial Sr ratios, were analyzed by XRF and ICP-MS for 11 major elements and 32 trace elements. Granitoids of the Shirakawa area intruding the Nohi Rhyolites in the Hida metamorphic terrane, belong to I-type magnetite series and contain commonly mafic enclaves. They are composed of a high $\mathrm{Na}_{2} \mathrm{O}$ group of monzodiorite to granodiorite and a low $-\mathrm{Na}_{2} \mathrm{O}$ group of biotite granites. The former is rich in mafic and calcic components, and was generated in mafic igneous source rocks of the Hida metamorphic terrane. The latter is felsic and leucogranitic, yet its $\mathrm{Rb} / \mathrm{Sr}$ is not high enough to be a fractionated magma. The leucogranite, typically of the Hirase body, could be a minimum melt generated from an intermediate igneous source. The Shirakawa granitoids are depleted in $\mathrm{Y}$ and HREE, implying the existence of garnet and hornblende in the source region.

Late Cretaceous-Paleogene granitoids occurring in the Mino sedimentary terrane belong to I-type ilmenite-series composed of high-level plutons of the Toki and Naegi areas and intermediate-level plutons of the Ryoke granitoids. These granitoids are reduced and per-aluminous implying genetic connection with sedimentary and less igenous sources. The Toki and Naegi bodies are composed mostly of biotite granite, intruding discordantly, and are rich in lithophile elements. The Naegi granite is especially high in $\mathrm{Rb}, \mathrm{Y}, \mathrm{Th}$, and $\mathrm{U}$ and its $\mathrm{Rb} / \mathrm{Sr}$ ratio is the highest among the studied rocks. Its REE pattern is flat with high HREE and a strong Eu anomaly, which could be considered as fractionated I type. The Ryoke granitoids are mostly biotite granite but horblende-biotite granodiorite is also common. They are less fractionated and have own geochemical characters compared with the Toki and Naegi granites. The studied granitoids have chemical compositions reflecting basically their basement characteristics, and also partly their degree of the magmatic fractionation.
\end{abstract}

\section{Introduction}

Parallelism between magnetite-series and ilmenite-series granitic belts is widely known along the Japanese Island arcs in late Cretaceous and Miocene granitic and volcanic belts (Ishihara, 1971b, 1973). In the Inner Zone batholith of Southwest Japan (Ishihara, 1990), magnetite-series granitoids tend to occur along the back-arc side of the Sanin-Shirakawa belt, while ilmenite-series granitoids are distributed in the fore-arc side of the Sanyo and Ryoke belts. This parallelism was considered to reflect the chemical contrast of the

${ }^{1}$ Institute of Geoscience, GSJ. s-ishihara@aist.go.jp

2 Rio Tinto Mining \& Exploration Ltd., 1821, Tower 2. China World Trade Centre, 1 Jianguomenwei Ave., Beijing 100004 , China source region for the granitic magmas (Ishihara and Terashima, 1977a).

In the Chubu District (Fig. 1), one of the type areas for magnetite- and ilmenite-series granitoids across the Honshu Island, the most distinctive feature is that, although Shirakawa granitoids of the Sanin-Shirakawa Belt to the north being mainly magnetite-bearing and granitoids of the Sanyo and Ryoke Belts to the south being generally magnetite-free ilmenite-series; both the magnetite- and ilmenite-series granitoids have the same latest Cretaceous-Paleogene age and similar high ${ }^{87} \mathrm{Sr} /{ }^{86} \mathrm{Sr}$ initial ratios ranging from 0.7096 to 0.7106 (Shibata and Ishihara, 1979a, b). The district is char-

Keywords: Late Cretaceous-Paleogene, granitoids, major chemistry, trace elements, Nohi Rhyolites, Shirakawa granitoids, Naegi Granite 
acterized by gravity low in the northern part of the Hida metamorphic terrane (Komazawa et al., 1999), reflecting a thick continental crust. These granitoids of this district having I-type characteristics (Chappell and White, 1992), should have originated within or greatly influenced by the continental crust.

Regional chemical variations of the granitoids across the Shirakawa-Toki-Okazaki transect were $\mathrm{s}$ lied by Ishihara and Terashima (1977a), who showed high $\mathrm{Fe}_{2} \mathrm{O}_{3} / \mathrm{FeO}$ ratios in the Shirakawa area and low $\mathrm{Fe}_{2} \mathrm{O}_{3} / \mathrm{FeO}$ ratios in the Sanyo-Ryoke Belts. The oxidized magmas were considered to reflect the high $\mathrm{Fe}_{2} \mathrm{O}_{3} / \mathrm{FeO}$ ratio of the source rocks, while the reduced magmas were interpreted to have been reduced by organic carbon from the accretionary sedimentary complex (Ishihara, 1984). In addition, a "constant-type" and an "increasing-type" for some lithophile elements plotted against the differentiation index, such as $\mathrm{F}, \mathrm{Li}, \mathrm{Rb}, \mathrm{Pb}, \mathrm{Sn}$ and $\mathrm{Be}$ in highly fractionated granites, were observed on the Shirakawa granitoids and the Toki-Naegi granites, respectively. These granitoids are also different in associated mineralizations: economic amounts of molybdenum deposits in the Shirakawa area, but tin-bearing tungsten deposits in the Naegi area (Ishihara, 1973). REE- and $\mathrm{U}$-Th-bearing minerals are nearly absent in the Shirakawa area, except for xenotime discovered in pegmatitic quartz vein of the Hirase deposit (Ishihara, 197la), but are very abundant in small but many peg. matites within the Naegi granite.

In order to understand the genesis of these two constrasting granitoid series, and also to detail the genetic variations within the Shirakawa and Naegi-Toki areas, a detailed chemical study was made here for major and trace elements on 66 samples, including 29 from Shirakawa granitoids, 26 from Toki, Naegi and Ryoke I granites and 11 from sorrounding rhyolitic country rocks. The analytical methods are XRF with glass-bead for major elements and pressed powder pellets for minor elements ( $\mathrm{V}, \mathrm{Ni}, \mathrm{Ga}, \mathrm{Rb}, \mathrm{Sr}, \mathrm{Ba}, \mathrm{Y}$, $\mathrm{Zr}$, Th and U), ICP-MS with acid digestion ( $\mathrm{Li}, \mathrm{Be}$, $\mathrm{Sc}, \mathrm{Cu}, \mathrm{Zn}, \mathrm{Rb}, \mathrm{Sr}, \mathrm{Ba}, \mathrm{Ga}$ and $\mathrm{Mo}$ ), and fusion decomposition (Y, Zr, Nb, Sn, Cs, Hf, Ta Pb, Th and $\mathrm{U})$. Details are given in $\mathrm{Wu}$ et al. (1993) and $\mathrm{Wu}$ and Ishihara (1994). The analytical results are listed in Appendices 1 through 3 and the studied areas are shown in Figs. 1 through 3.

\section{Geologic Background}

\subsection{Shirakawa Area}

The Shirakawa granitoids located in the Hida metamorphic terrane of Hida gneisses and Triassic-Jurassic I-type Funatsu granitoids, occur as a group of granitic stocks intruding coeval felsic welded tuffs called "Nohi Rhyolites", which have been classified into six sequences in the central and southern parts. Their

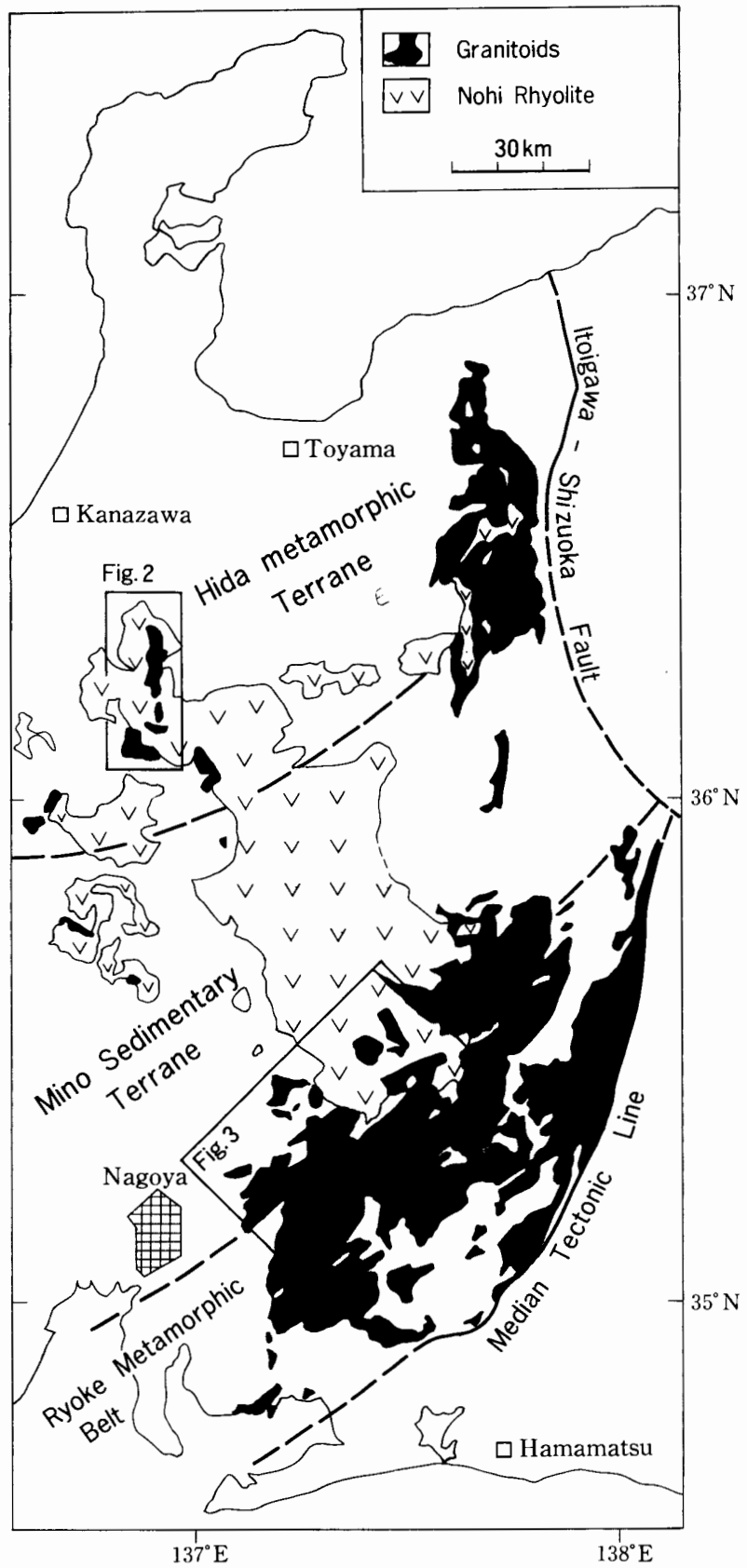

Fig. 1 Distribution of the late Cretaceous-Paleogene granitoids and associated Nohi rhyolites, and the studied areas in the Chubu District.

CHIME (Chemical Th-U-total $\mathrm{Pb}$ isochron method) and $\mathrm{Rb}-\mathrm{Sr}$ ages vary from 86 to $56 \mathrm{Ma}$ (Koido and Yamada, 1999). The main granitic bodies are, from north to south, Hatogaya (granodiorite to monzogranite, but referred here as granite), Hirase (granite), Mihoro (granodiorite), Awaradani (granodiorite) and Fukushimadani (granite) (Fig. 2). A Rb-Sr whole-rock isochron for these granitoids indicates an age of $65.6 \pm 1.8 \mathrm{Ma}$ with the initial ${ }^{87} \mathrm{Sr} /{ }^{86} \mathrm{Sr}$ ratio of $0.7100 \pm 0.0002$ (Shibata and Ishihara, 1979a, b).

The granitoids comprise amphibole-biotite granodiorite and biotite granite. They are fine-grained and 


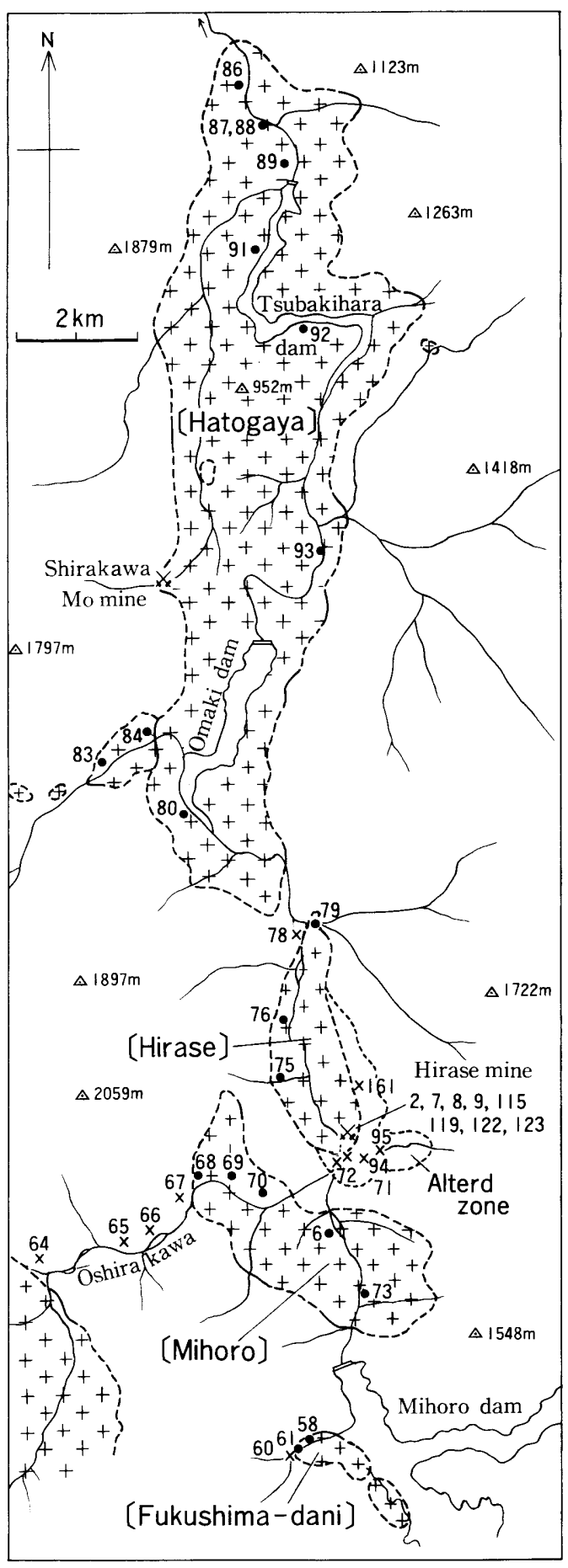

Fig. 2 Distribution of the Shirakawa granitoids (crossed part) and Nohi Rhyolites (blank part), and locality of the analyzed samples. granitoids; $\times$ Nohi Rhyolites, with the last two digits of the sample numbers in Appendices 1 and 2.

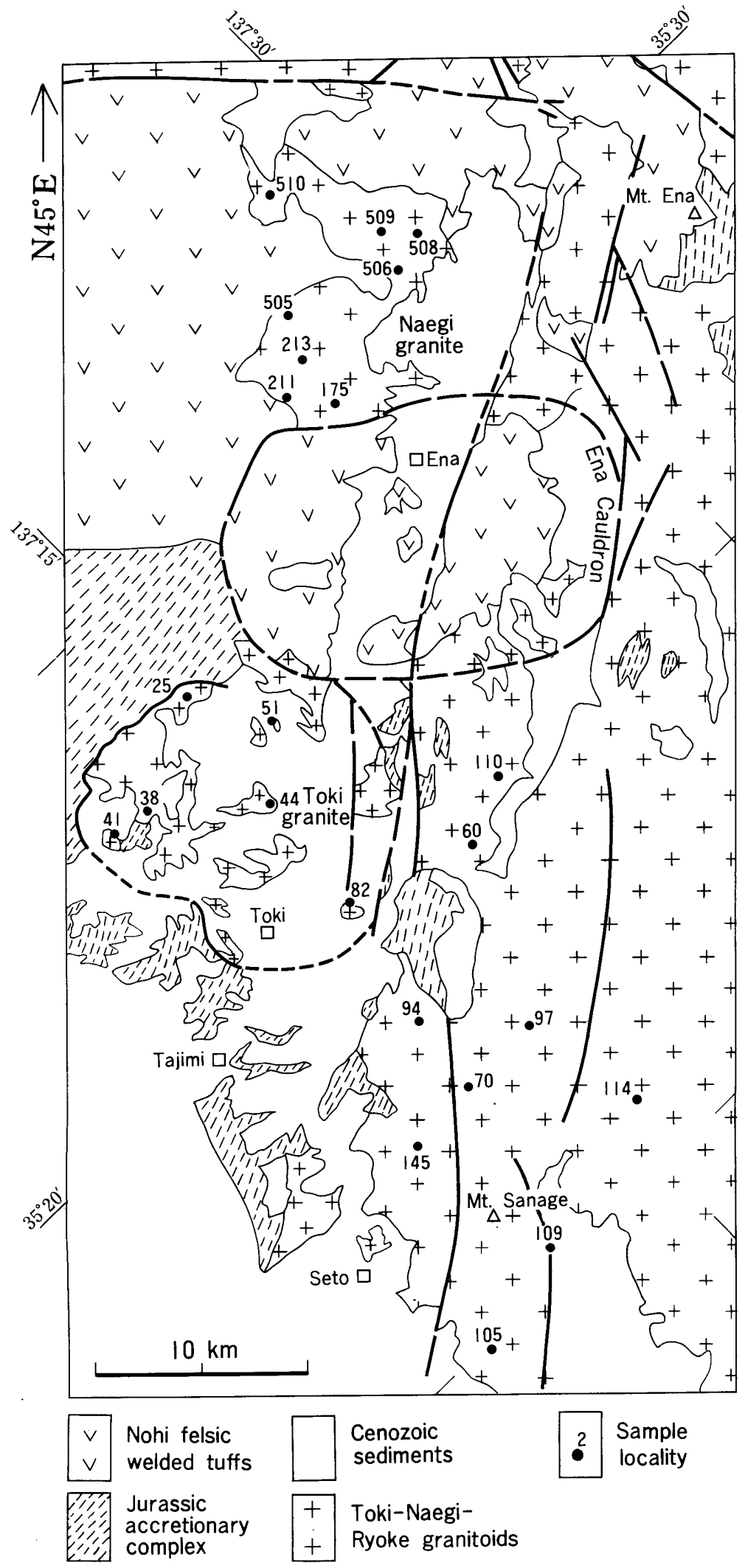

Fig. 3 Distribution of the Naegi-Toki-Ryoke granitoids, Chubu District. The Ena cauldron is taken from Yamada (1989). Solid circle, locality of the analyzed granitoids with the last two digits of the sample numbers in Appendix 3. 
high level. The analyzed samples were selected from various bodies shown in Fig. 2. No sedimentary enclaves are present in the granitoids but mafic igneous enclaves are found. Conglomerate-looking mafic enclaves hosted in leucogranites (see Plate LXI of Ishihara, 1971a) are typically seen in the northern part of the Hatogaya body. The most mafic rock among the analyzed samples (Fig. 2), e.g., no. 88 (hereafter the last two digits on the sample numbers are shown), is such an enclave monzodiorite.

The Hirase body is composed of the main phase granite of ${ }_{72} \mathrm{bG}_{3}$, which should be read a biotite monzogranite with color index of $3 \mathrm{vol}$. percent (mostly biotite) and the grain-size index (number of grain boundary of the rock-forming minerals in $25 \mathrm{~mm}$ distance, see Ishihara, 1971a) of 72 and marginal finer phase of ${ }_{142} \mathrm{~b} / \mathrm{mG}_{2}$, which is finer, leucocratic phase with biotite and little muscovite. They can be called haplogranite of Tuttle and Bowen (1958).

The granitoids have $\mathrm{A} / \mathrm{CNK}$ ratios (mol. $\mathrm{Al}_{2} \mathrm{O}_{3} / \mathrm{CaO}+\mathrm{Na}_{2} \mathrm{O}+\mathrm{K}_{2} \mathrm{O}$ ) between 0.95 and 1.06 (Appendix 2), which are lower than the S-type limit of 1.1 (Chappell and White, 1992), implying all the granitoids belong to I type. The magnetic susceptibility varies from $765 \times 10^{-6}$ for quartz monzodiorite to 100 $\mathrm{x} 10^{-6} \mathrm{emu} / \mathrm{g}$ for granite. These are slightly lower than the typical values found in the major Mo-mineralized area of the Sanin district (Ishihara, 1971a). The Awaradani granodiorite body is an exception having the magnetic susceptibility lower than $100 \times 10^{-6} \mathrm{emu} / \mathrm{g}$, being thus I-type/ilmenite series.

The Nohi Rhyolites, comprising mostly dacitic-rhyolitic pyroclastic rocks which have been welded, are considered to be comagmatic with the granitoids (Yamada, 1977). In the Shirakawa area, the Nohi Rhyolites have received a weak propylitic alteration and thermally metamorphosed by intrusion of the nearby granitoids; e.g., Fukushima-dani granite (see Plate LXI, Ishihara 1971a), and hydrothermally altered around the Mo-mineralized stock at Hirase. Thus, the alteration is considered to be "contact" hydrothermal alteration (Ishihara, 1971a), and shows following zones, from the Hirase granite outwards: (1) andalusite-biotite-sericite zone and/or (2) siderite-sericite zone, and then (3) calcite-chlorite zone.

Molybdenite-quartz veins are widely distributed in the Shirakawa area (Fig. 1). At the Hirase mine (Onishi et al., 1973), hosted in leucogranite of the Hirase stock, production (1941-1974) of molybdenite concentrates amounts to 2,692 tons $\left(\mathrm{MoS}_{2} 97 \%\right)$. The next largest production of ca.40 tons comes from the Shirakawa Suien (Mo) veins occurring at the western margin of the Hatogaya stock. The Hirase veins striking N-S and dipping vertically contain beautiful euhedral crystals of molybdenite and accessory amounts of $\mathrm{K}$-feldspar, xenotime, and base metal and iron sulfides. The vein walls have been carbonitized and serici- tized, but not greisenized.

\subsection{Naegi-Toki-Sanage Area}

Around the southern margin of the Nohi Rhyolites, high-level granitoids intrude into the volcanic and subvolcanic rocks of the Nohi Rhyolites and Jurassic sedimentary rocks of the Mino accretionary complex (Fig. 1). The volcanic rocks are not exposed to the south but the sedimentary rocks which have been regionally metamorphosed, implying deeper levels of the granitoids, are seen in the southern area. All the granitoids have magnetic susceptibility below $12-18 \times 10^{-6}$ $\mathrm{emu} / \mathrm{g}$, thus belonging to the ilmenite series.

\subsubsection{Naegi Granite}

The Naegi granite intrudes the southeastern margin of the Nohi Rhyolites (Fig. 3). The intrusion is controlled by NNW-trending faults, which correspond to the most distinct fracture system for the Nohi Rhyolites, and NE-trending faults which bound the Ryoke granitoids to the south. A cauldron structure, NW-SE $15 \mathrm{~km}$ by NE-SW $13 \mathrm{~km}$, was proposed to the southwest of the Naegi granite (Yamada, 1989). The Naegi granite is magnetite-free biotite granite with a medium-grain size. It also includes very fine-grained chilled margin, called "Nukame" stone by building stone miners, which occurs along the western rim (Kawata, 1961). Four samples each were selected from the western part (nos. 175, 211, 213, 505) and the eastern part (nos. 506, 508, 509, 510). They show A/CNK ratio of $1.02-1.05$ (Appendix 3).

The granite contains many drusy-type pegmatites, ranging from a few centimeters to a few tens of centimeters in diameter. The drusy pegmatites in particular are well known to contain beautiful crystals of smoky quartz, K-feldspar, micas and accessory amounts of zircon and its REE-rich variety of naegite, fergusonite, samarskite, monazite, allanite, enalite - a REE-rich variety of uranothorite, xenotime and gadolinite. According to Koseki and Matsubara (1961), these minerals were found in the following numbers of localities: naegite, (15 localities), fergusonite (11), monazite (6), samarskite (6), allanite (5), enalite (4), gadolinite (4), xenotime (4) and zircon (3). Wolframite-quartz vein deposits with greisenization are known to occur within granite (Fukuoka mine) and in pyroclastic rocks of the Nohi Rhyolites (Ebisu and Togane mines). Including minor ore deposits, the following metallogenic zonings are observed from the Naegi granite northward: I pegmatite zone, II W-Sn-Bi zone, III $\mathrm{W}-\mathrm{As}-\mathrm{Bi}$ zone, and IV $\mathrm{Cu}-\mathrm{Pb}-\mathrm{Zn}-\mathrm{As}$ zone (Sakamaki et al., 1961).

\subsubsection{Toki Granite}

The Toki granite occurs to the west of the Naegi granite intruding Paleozoic-Mesozoic sedimentary rocks. It has a circular form, N-S $14 \mathrm{~km}$ by E-W 12 
$\mathrm{km}$ (Fig. 3), and is composed mostly of fine- to medium-grained biotite granite. Granodiorite is present only at the northwestern portion (Suzuki and Ishihara, 1969). Both are magnetite free. Seven samples, two hornblende-bearing, were selected for the chemical analyses. A/CNK ratio of this body (1.09-1.16, Appendix 3), straddling on the $\mathrm{S} / \mathrm{I}$ type boundary of 1.1 , is more aluminous than the Naegi granite. The Toki granitoids have a $\mathrm{Rb}-\mathrm{Sr}$ whole rock age of 72.3 $\pm 3.9 \mathrm{Ma}$ and initial Sr ratio of $0.7106 \pm 0.0001$ (Shibata and Ishihara, 1979a).

In contrast to the Naegi granite, the Toki granite contains only a few pegmatites and is not associated with any economic grade of metallic mineralization. Absence of the Nukame granite and drusy pegmatite indicates that the Toki granite crystallized at deeper levels than the Naegi granite.

\subsubsection{Ryoke Granitoids}

Granitoids distributed to the south of the Naegi and Toki granites around Mt. Sanage (Fig. 3) intrude mainly Jurassic sedimentary accretionary complex rocks with no or low-grade Ryoke metamorphism. The granitoids are the Ryoke I granitoids of Ishihara and Terashima (1977a). The granitoids intrude locally into the Nohi Rhyolites in the north (Yamada and Nakai, 1969), and older granitoids to the south.

These granitoids consist largely of medium- to coarse-grained hornblende-biotite granodiorite and biotite granite. They contain no magnetite. Rare foliated granitoids which occur within in the massive granitoids may be the remnants of older syntectonic granitoids (e.g., nos. 97, 139). Some of the leucocratic biotite granites have been classified as Naegi granite (e.g. Yamada et al., 1974), although they have distinctive chemical characteristics, compared with the Naegi Granite at the type locality (Ishihara and Terashima, 1977a). The leucoratic granites have S-type A/CNK ratios (1.17-1.18, Appendix 3), while the other, more mafic granitoids show generally I-type ratios.

No pegmatite is present, but some aplitic dikelets are observed. No metallic ore deposits are known in and around the Ryoke granitoids. These field observations and the wide exposure of the Ryoke granitoids suggest a deeper level is now exposed in the Ryoke Belt.

\section{Analytical Results}

\subsection{Shirakawa Area}

\subsubsection{Volcanic rocks}

The Nohi Rhyolites analyzed in the Oshirakawa-Hirase area (Fig. 1) have $\mathrm{SiO}_{2}$ contents of 68.4 -76.6 percent (average $70.3 \%, n=6$. Appendix 1). Granitoids of the same area including the Mihoro, Hirase (only those from surface) and Fukushima-dani plutons have a similar range from 68.0 to 76.4 percent but are different on average $(73.4 \%, n=11$, Appendix 2). Thus, the grani- toids became more silicic than the volcanic rocks. In the Harker's diagram though not shown here, the granitoids are also richer than the rhyolites in $\mathrm{Al}_{2} \mathrm{O}_{3}$, $\mathrm{Na}_{2} \mathrm{O}, \mathrm{TiO}_{2}, \mathrm{MgO}$ but lesser in $\mathrm{K}_{2} \mathrm{O}$ and total $\mathrm{Fe}_{2} \mathrm{O}_{3}$.

The Nohi Rhyolites at the eastern margin of the Hirase pluton has experienced "contact" hydrothermal alteration. Chemical compositions of the unaltered rhyolites (nos. 64, 65, 66, 67, average $\mathrm{SiO}_{2} 73.8 \%$, $\mathrm{n}=4$ ) and altered rhyolites (nos. 71, 72, 94, 95161 , average $\mathrm{SiO}_{2} 74.9 \%, \mathrm{n}=6$ ) can be summarized as follows:

(1) Ferromagnesian components including total $\mathrm{Fe}_{2} \mathrm{O}_{3}$, $\mathrm{MgO}, \mathrm{TiO}_{2}, \mathrm{~V}, \mathrm{Cr}$ and $\mathrm{Ni}$ are strongly decreased in the altered rhyolites, reflecting break down of the original ferromagnesian minerals.

(2) $\mathrm{Sr}$ (143 ppm average) and $\mathrm{Ba}$ (633 ppm average), are lower in the altered rocks ( $\mathrm{Sr} 28 \mathrm{ppm}$ and $\mathrm{Ba} 144 \mathrm{ppm}$, respectively), implying these elements were depleted during recrystallization of the feldspars.

(3) Both $\mathrm{Zr}(159 \mathrm{ppm})$ and $\mathrm{Hf}(4.8 \mathrm{ppm})$ are slightly increased (220 ppm and $7.0 \mathrm{ppm}$, respectively) in the altered rocks.

(4) Total LREE (La to Sm) have increased from 131.4 ppm to $223.4 \mathrm{ppm}$; no clear changes are evident for the HREE (Gd to Lu).

\subsubsection{Granitic rocks}

Granitoids of the Shirakawa area, i.e., Shirakawa granitoids, have a wide range of $\mathrm{SiO}_{2}$ content from 60 to 77 percent (Appendix 2). Those with 60-63 percent $\mathrm{SiO}_{2}$ occur as mafic enclaves or blocks in the Hatogaya body. The Mihoro body is composed of granodiorite with 68-70 percent $\mathrm{SiO}_{2}$. The Hirase body is characterized by high silica rocks of 71-77 percent $\mathrm{SiO}_{2}$. The reconnaissance study indicates that the Shirakawa granitoids are rich in $\mathrm{Na}_{2} \mathrm{O}$, as compared with the Naegi-Toki-Ryoke granitoids (Ishihara and Terashima, 1977a). $\mathrm{Na}_{2} \mathrm{O}$ apparently decreases with increasing $\mathrm{SiO}_{2}$ towards 3.6 percent $\mathrm{Na}_{2} \mathrm{O}$ of the eutectic minimum (Tuttle and Bowen, 1958). In more details, however, the Shirakawa granitoids can be divided into two groups (Fig. 4):

(A) high $\mathrm{Na}_{2} \mathrm{O}$-low $\mathrm{SiO}_{2}$ group; $\mathrm{Na}_{2} \mathrm{O} 4.61 \% ; \mathrm{SiO}_{2}$ $68.4 \%$ in average $(\mathrm{n}=11)$ and

(B) low $\mathrm{Na}_{2} \mathrm{O}$-high $\mathrm{SiO}_{2}$ group; $\mathrm{Na}_{2} \mathrm{O} 3.79 \% ; \mathrm{SiO}_{2}$ $75.5 \%$ in average $(n=17)$ (Fig. 4$)$.

Their average compositions are listed in Table 1.

Mafic enclaves and blocks of the Hatogaya body (nos. 86, 88), the granitoids of the attached Aradani body (nos. 83, 84), a small part of the Hirase granitic body (nos. 8,115 ) and all of the Mihoro granodiorite body (nos. 6, 68, 69, 70, 73), belong to the high $\mathrm{Na}_{2} \mathrm{O}$ group. The low $\mathrm{Na}_{2} \mathrm{O}$ group, on the other hand, is composed of all the granitoids of the Hatogaya body (nos. $80,87,89,91,92,93$ ), most of the Hirase granitic body (nos. 2, 7, 9, 119, 123; 13, 75, $76,79,122)$, and the Fukushima-dani granitic body 
Table 1 Average major and selected trace element compositions of the studied granitoids from the Chubu District.

\begin{tabular}{|c|c|c|c|c|c|}
\hline & \multicolumn{2}{|c|}{ Magnetite Series } & \multicolumn{3}{|c|}{ Mmenite Series } \\
\hline & High $\mathrm{Na}_{2} \mathrm{O}$ group & Low $\mathrm{Na}_{2} \mathrm{O}$ group & Ryoke & Toki & Naegi \\
\hline Number of analyses & 11 & 17 & 8 & 6 & 8 \\
\hline $\mathrm{SiO}_{2}$ & $68.43 \%$ & $75.45 \%$ & $73.37 \%$ & $73.39 \%$ & $76.67 \%$ \\
\hline $\mathrm{TiO}_{2}$ & 0.42 & 0.13 & 0.18 & 0.14 & 0.05 \\
\hline $\mathrm{Al}_{2} \mathrm{O}_{3}$ & 15.24 & 12.97 & 14.26 & 14.09 & 12.67 \\
\hline Total $\mathrm{Fe}_{2} \mathrm{O}_{3}$ & 3.27 & 1.25 & 1.82 & 1.74 & 1.11 \\
\hline $\mathrm{MnO}$ & 0.11 & 0.05 & 0.06 & 0.06 & 0.03 \\
\hline $\mathrm{MgO}$ & 1.00 & 0.24 & 0.34 & 0.26 & 0.04 \\
\hline $\mathrm{CaO}$ & 2.75 & 0.90 & 1.65 & 1.33 & 0.73 \\
\hline $\mathrm{Na}_{2} \mathrm{O}$ & 4.61 & 3.79 & 3.15 & 3.48 & 3.52 \\
\hline $\mathrm{K}_{2} \overline{\mathrm{O}}$ & 3.07 & 4.32 & 4.33 & 4.25 & 4.74 \\
\hline $\mathrm{P}_{2} \mathrm{O}_{5}$ & 0.13 & 0.04 & 0.05 & 0.06 & $<0.01$ \\
\hline Ig. loss & 0.71 & 0.60 & 0.73 & 0.72 & 0.45 \\
\hline Total & 99.75 & 99.74 & 99.95 & 99.92 & 100.00 \\
\hline Color Index & 4.80 & 1.67 & 2.40 & 2.20 & 1.23 \\
\hline $\mathrm{TFe}_{2} \mathrm{O}_{3} / \mathrm{MgO}$ & 3.3 & 5.2 & 5.4 & 6.7 & 27.8 \\
\hline $\mathrm{Zn}$ & $55 . \overline{\mathrm{ppm}}$ & $23.5 \mathrm{ppm}$ & $33.5 \mathrm{ppm}$ & $39.7 \mathrm{ppm}$ & $20.9 \mathrm{ppm}$ \\
\hline $\mathrm{Ba}$ & 672 & 502 & 477 & 371 & 76.9 \\
\hline $\mathrm{Pb}$ & 12.6 & 13.9 & 29.1 & 31.8 & 28.8 \\
\hline $\mathrm{Rb}$ & 100 & 142 & 182 & 232 & 289 \\
\hline $\mathrm{Sr}$ & 281 & 98.7 & 106 & 99.0 & 22.6 \\
\hline $\mathrm{Rb} / \mathrm{Sr}$ & 0.36 & 1.43 & 1.72 & 2.34 & 12.8 \\
\hline $\mathrm{Zr}$ & 189 & 103 & 90.4 & 112 & 86.3 \\
\hline Hf & 5.2 & 3.5 & 3.1 & 3.7 & 3.9 \\
\hline $\mathrm{Zr} / \mathrm{Hf}$ & 36.4 & 29.5 & 29.2 & 30.3 & 22.1 \\
\hline Th & 9.4 & 13.9 & 19.4 & 24.0 & 32.0 \\
\hline $\mathrm{U}$ & 2.0 & 4.5 & 4.0 & 5.5 & 9.1 \\
\hline Y & 25.7 & 21.4 & 37.1 & 54.7 & 78.4 \\
\hline REE & 160 & 130 & 134 & 140 & 162 \\
\hline
\end{tabular}

High $\mathrm{Na}_{2} \mathrm{O}$-group: $\mathrm{Nos}, 86,88,83,84,8,115,6,68,69,70,73$. Low $\mathrm{Na}_{2} \mathrm{O}$-group: Nos.87, 89, 91, 92, 93, 80 , $3,7,9,119,123,13,75,76,79,122,58$. For the ilmenite-series granitoids, those with $\mathrm{SiO}_{2}$ higher than $70 \%$ were selected. Ryoke: $105,110,109,114,94,60,145,70$. Toki: T38, T44, T51, T82, T25, T2. Naegi: 175A, 213, $211,505,506,508,509,510$.

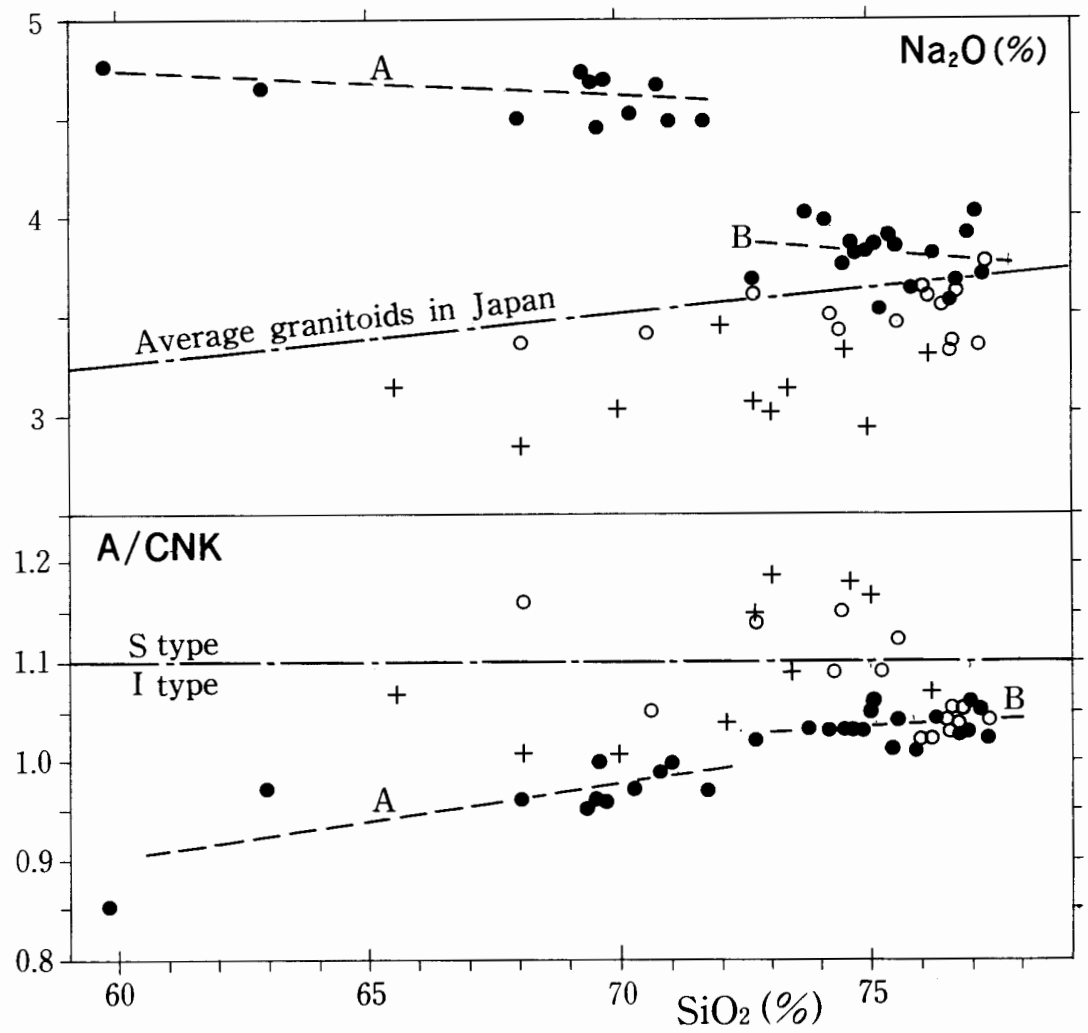

Fig. 4 Two distinctive trends on $\mathrm{Na}_{2} \mathrm{O}$ (wt. \%) and $\mathrm{A} / \mathrm{CNK}\left(\mathrm{mol} . \mathrm{Al}_{2} \mathrm{O}_{3} / \mathrm{CaO}+\mathrm{Na}_{2} \mathrm{O}+\mathrm{K}_{2} \mathrm{O}\right.$ ) of the Shirakawa and Naegi-Toki-Ryoke granitoids. Solid circle, Shirakawa granitoids; open circle, Toki and Naegi granitoids; cross, Ryoke granitoids. Broken line with $\mathrm{A}$ and $\mathrm{B}$, general trend for the Shirakawa granitoids. Dotted broken line for $\mathrm{Na}_{2} \mathrm{O}$ is average composition of the Japanese granitoids ( $\mathrm{S}$. Ishihara, unpublished data), and for A/CNK is S-type and I-type boundary proposed by Chappell and White (1992). 
(nos. 58, 61). Both types of granitoids occur together in the Hatogaya body, related to the mingling occurrence of mafic enclaves in this body.

The high $\mathrm{Na}_{2} \mathrm{O}$ group is rich in both mafic and calcic components, such as $\mathrm{TiO}_{2}, \mathrm{Al}_{2} \mathrm{O}_{3}$, Total $\mathrm{Fe}_{2} \mathrm{O}_{3}$, $\mathrm{MnO}, \mathrm{MgO}, \mathrm{CaO}, \mathrm{P}_{2} \mathrm{O}_{5}, \mathrm{Zn}$ and $\mathrm{Sr}$, while the low $\mathrm{Na}_{2} \mathrm{O}$ group has higher $\mathrm{SiO}_{2}, \mathrm{~K}_{2} \mathrm{O}, \mathrm{Rb}$, Th and $\mathrm{U}$. It is considered unusual that the high $\mathrm{Na}_{2} \mathrm{O}$ group is also high in $\mathrm{Ba}, \mathrm{Zr}, \mathrm{Y}$ and REE. In Fig. 5, it is evident that $\mathrm{Rb}$ is not "constant type" (Ishihara and Terashima, 1977a) but rather shows a weak positive correlation with $\mathrm{SiO}_{2}$ within each group. $\mathrm{Ba}$ is approximately constant in the high $\mathrm{Na}_{2} \mathrm{O}$ group, but drops sharply with increasing $\mathrm{SiO}_{2}$ in the low $\mathrm{Na}_{2} \mathrm{O}$ group (Fig. 5). $\mathrm{Sr}$ decreases with decreasing $\mathrm{CaO}$ and is slightly higher in the Shirakwa granitoids than the Naegi-Toki-Ryoke granitoids.

Athough all the low $-\mathrm{Na}_{2} \mathrm{O}$ group granitoids are high in $\mathrm{SiO}_{2}$, hence in normative $\mathrm{ab}+$ or $+\mathrm{qz}$ (see Ishihara 1971a), and may be called haplogranite (Bowen abd Tuttle, 1958); yet their $\mathrm{Rb} / \mathrm{Sr}$ ratios range from as low as 0.5 to 8.7 (Fig. 6). These values are similar to unfractionated I-type haplogranites of the Lachlan Fold Belt (Chappell, 1999). These low $\mathrm{Na}_{2} \mathrm{O}$ granites are, therefore, considered a minimum melt of the original magmas, rather than its fractionated products.

REE contents of the high $\mathrm{Na}_{2} \mathrm{O}$ group vary from higher in the low $\mathrm{SiO}_{2}$ end-members (e.g., nos. 86, 88) to lower in the high $\mathrm{SiO}_{2}$ rocks; the latter are depleted particularly in HREE (Fig. 7A). The high $\mathrm{Na}_{2} \mathrm{O}$ granitoids reveal weak negative $\mathrm{Eu}$ anomalies. Granodiorites of the Mihoro body show very similar REE patterns to those of Fig. 7A, but no Eu anomaly is observed.

Among the low $\mathrm{Na}_{2} \mathrm{O}$ group, granitoids of the Hatogaya body show a wide variation of Eu anomalies and

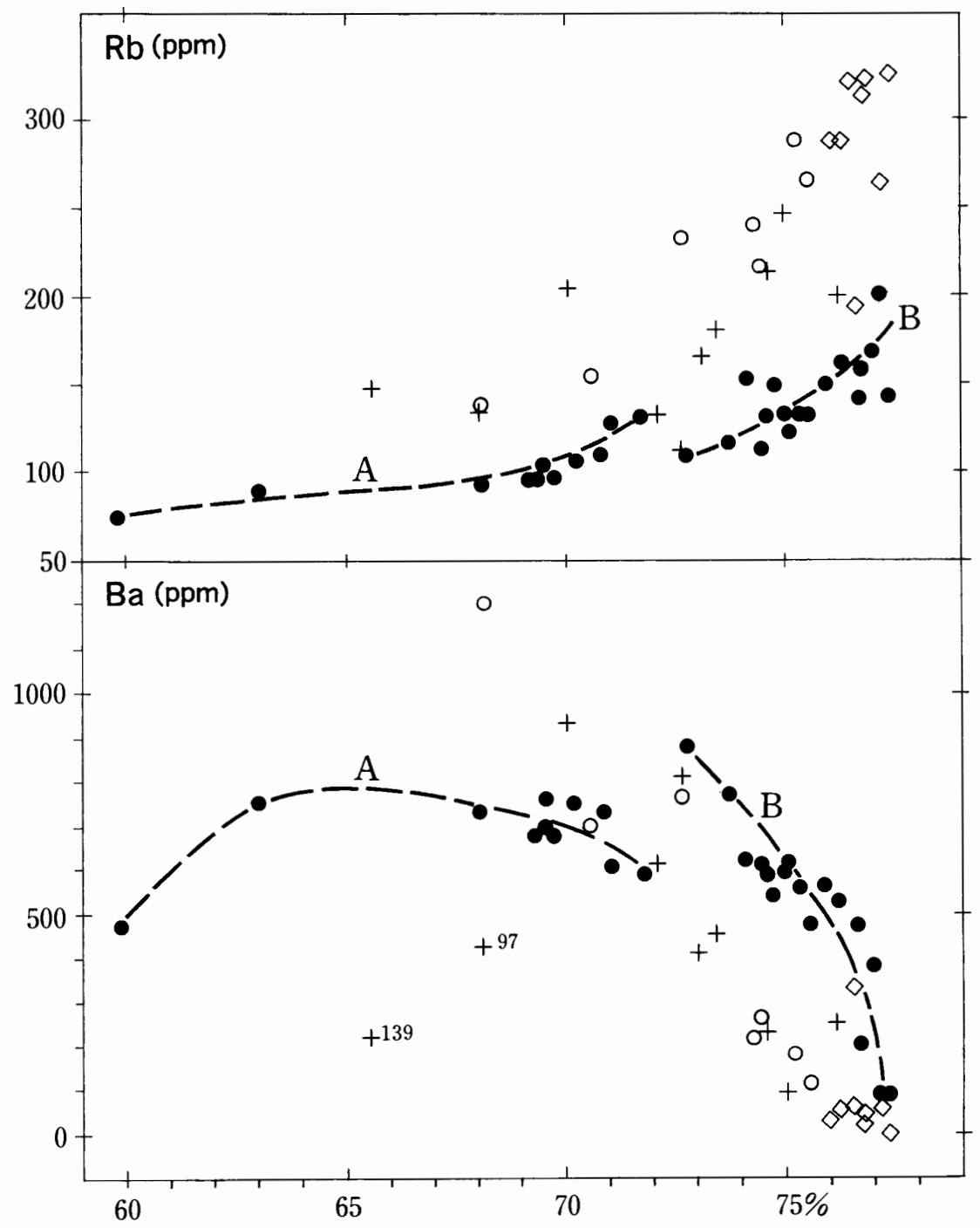

Fig. $5 \mathrm{Rb}$ and $\mathrm{Ba}$ vs. $\mathrm{SiO}_{2}$ diagrams of the studied magnetite-series and ilemenite-series granitoids. Solid circle, Shirakawa granitoids with the high $\mathrm{Na}_{2} \mathrm{O}$ trend (A) and low $\mathrm{Na}_{2} \mathrm{O}$ trend (B). Open circle, Toki granitoids; open diamond, Naegi granite; cross, Ryoke granitoids. Two granodiorites of the Ryoke Belt (nos. 139, 97) are plotted in low Ba area. 


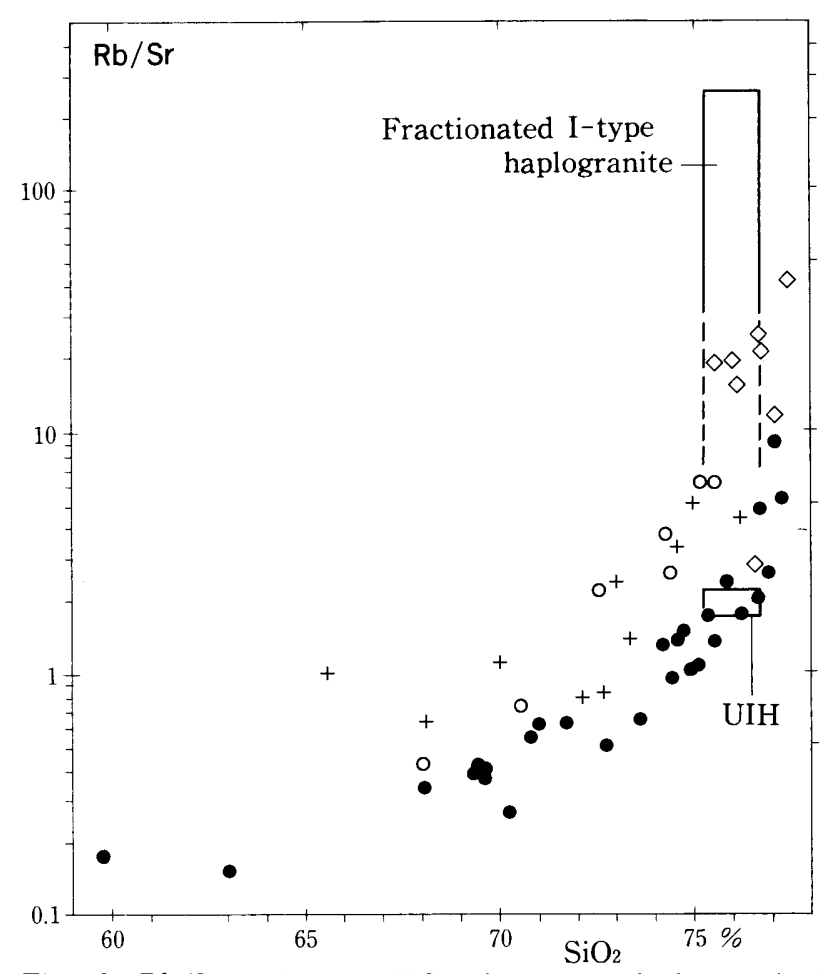

Fig. $6 \mathrm{Rb} / \mathrm{Sr}$ ratio vs. $\mathrm{SiO}_{2}$ diagrams of the studied magnetite-series and ilemenite-series granitoids. Solid circle, Shirakawa granitoids; open circle, Toki granitoids; open diamond, Naegi granite; cross, Ryoke granitoids. Areas of UIH, unfractionated I-type haplogranite and fractionated I-type haplogranite of Chappell (1999).
HREE contents (Fig. 7B). Granitoids occurring in the northern part (nos. 87, 89) have similar LREE patterns to those of the associated monzodiorite but depleted in HREE (compare Figs. 7A and B). Granitoids of the central (nos. 91, 92) and southern parts (nos. 80, 93) reveal a sharp decreasing of both the LREE and Eu, and show strong Eu anomalies.

In the Hirase body, REE patterns of the main biotite granite phase (nos. $13,75,76,79,122$ ), are similar to those of the low $-\mathrm{Na}_{2} \mathrm{O}$ granites of the Hatogaya body (e.g., no. 93). Finer-grained phase of the same body show also similar pattern.

\subsection{Naegi-Toki-Sanage Area}

The Naegi, Toki and Ryoke granitoids appear to be different in the present erosion level by differential movement along the NE-SW regional faults, and they may also be different in the magma sources. In order to test this hypothesis, some elements pertinent to magmatic fractionation are shown in Table 1. Compared to the Toki granitoids, the Naegi granite is higher in $\mathrm{SiO}_{2}, \mathrm{~K}_{2} \mathrm{O}, \mathrm{Na}_{2} \mathrm{O}+\mathrm{K}_{2} \mathrm{O}, \mathrm{Fe}_{2} \mathrm{O}_{3} / \mathrm{MgO}, \mathrm{Rb}, \mathrm{Y}$, $\mathrm{Th}, \mathrm{U}$ and $\mathrm{REE}$, but lower in total $\mathrm{Fe}_{2} \mathrm{O}_{3}, \mathrm{MgO}$, $\mathrm{CaO}$, Sr and $\mathrm{Ba}$. Average $\mathrm{Rb} / \mathrm{Sr}$ ratios are 12.8 for the Naegi granite, versus 2.3 for the Toki granitoid. Because of their depleted $\mathrm{MgO}$, the average total $\mathrm{Fe}_{2} \mathrm{O}_{3} / \mathrm{MgO}$ ratio is much higher in the Naegi granite (27.8) than in the Toki granite (6.7). Thus, these parameters indicate that the Naegi granite is much more

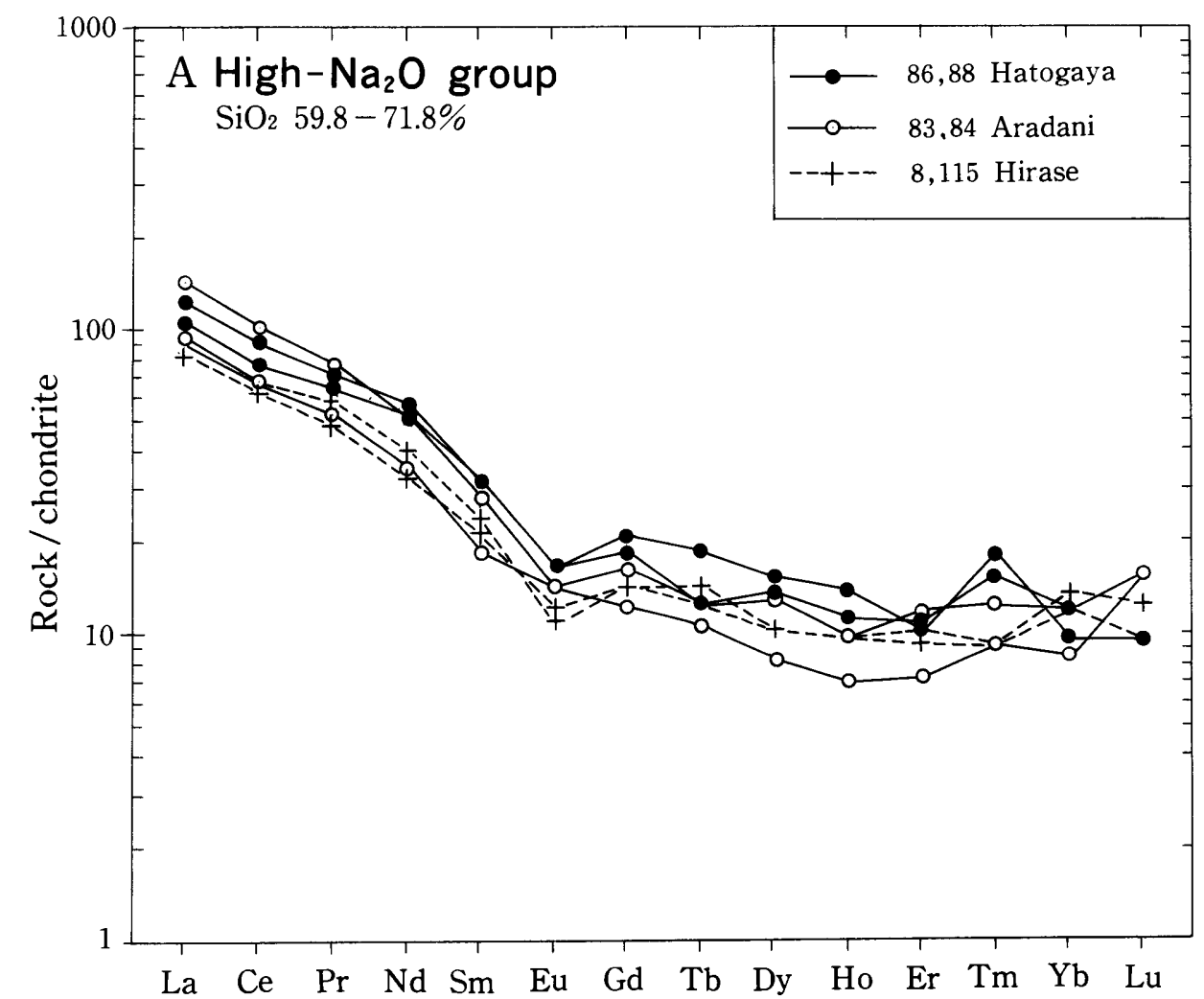

Fig. 7A Representative REE patterns of the Shirakawa granitoids, Chubu District. 


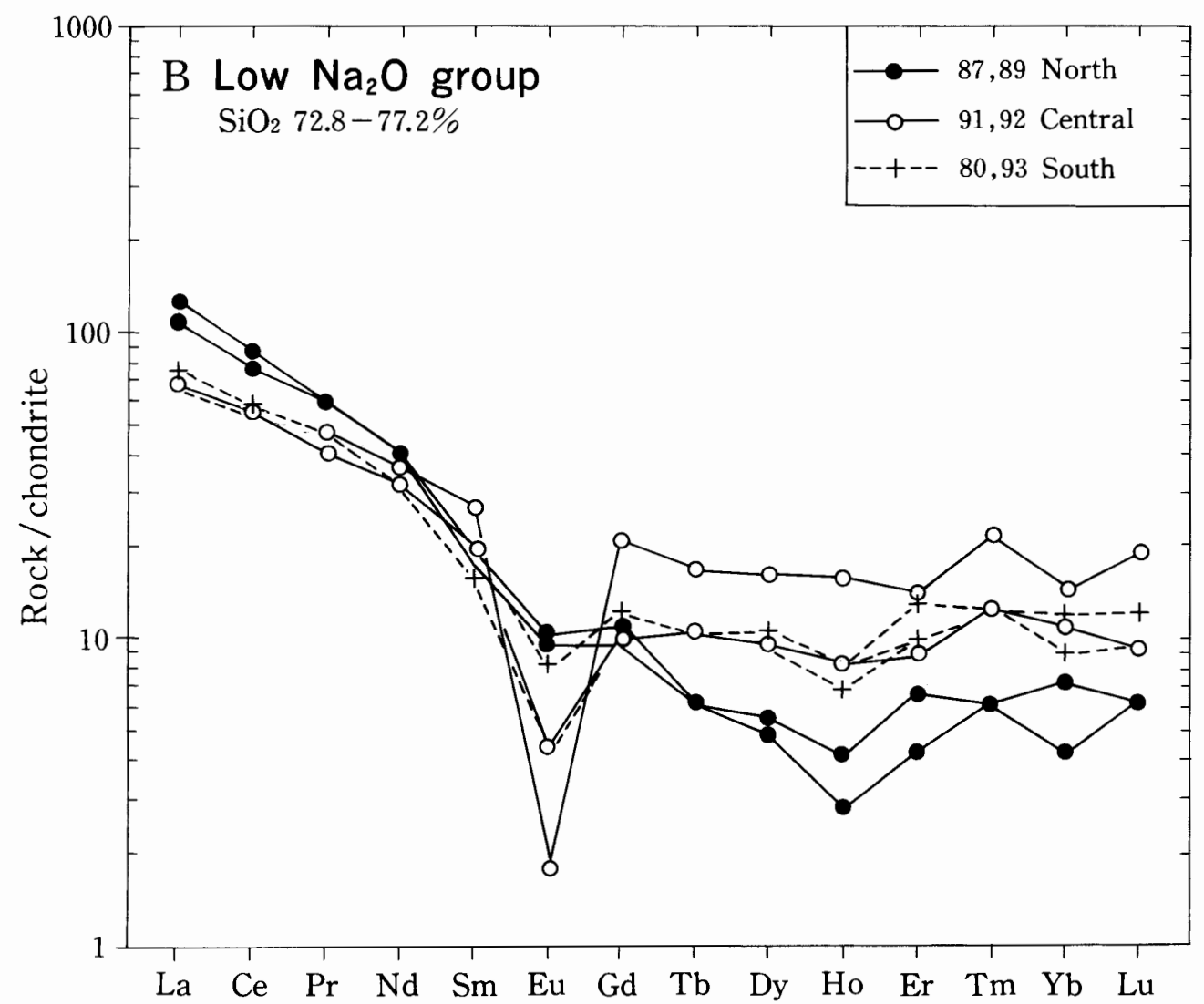

Fig. 7B Representative REE patterns of the Shirakawa granitoids, Chubu District.

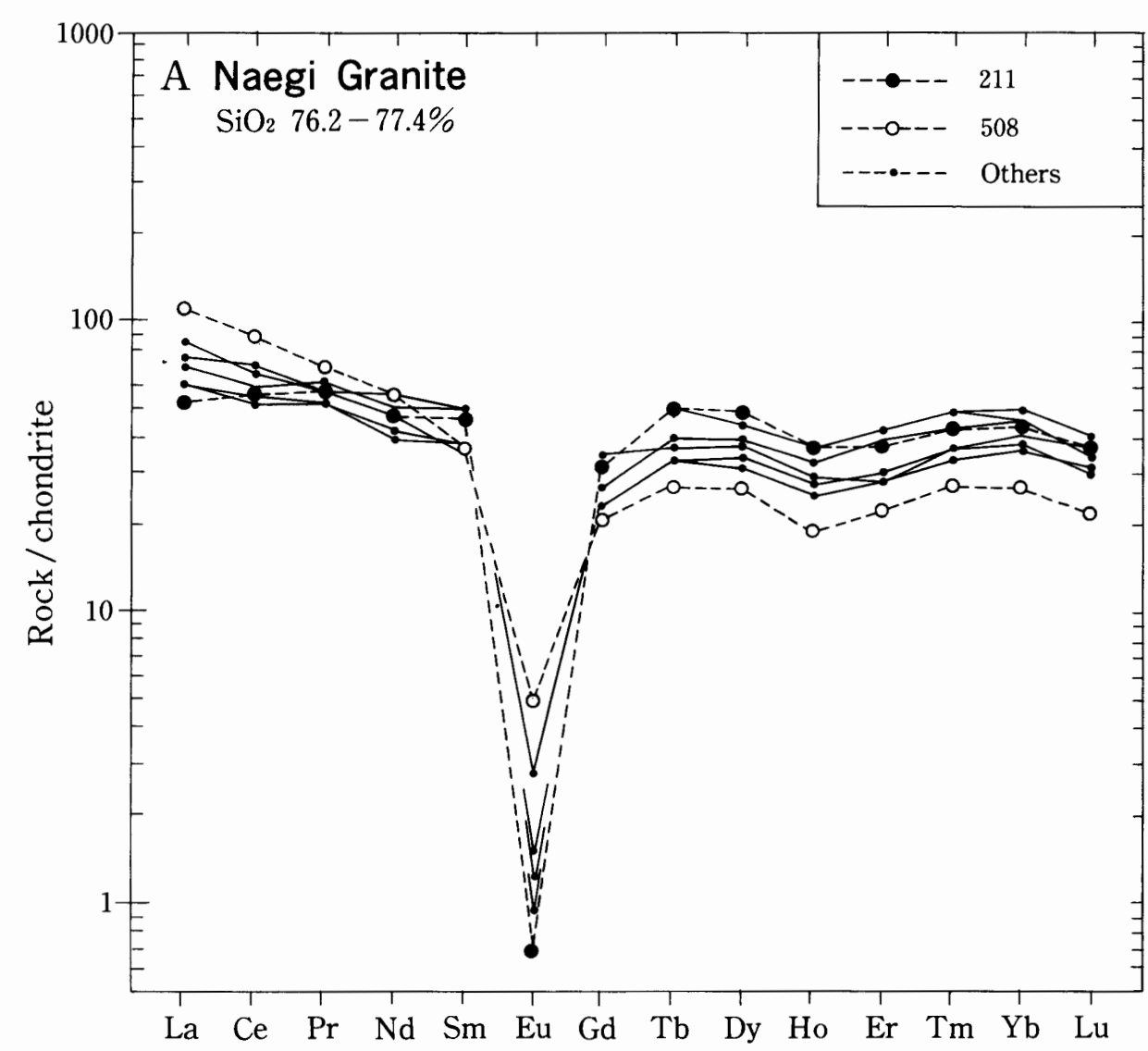

Fig. 8A Representative REE patterns of the Naegi and Toki granitoids, Chubu District. 


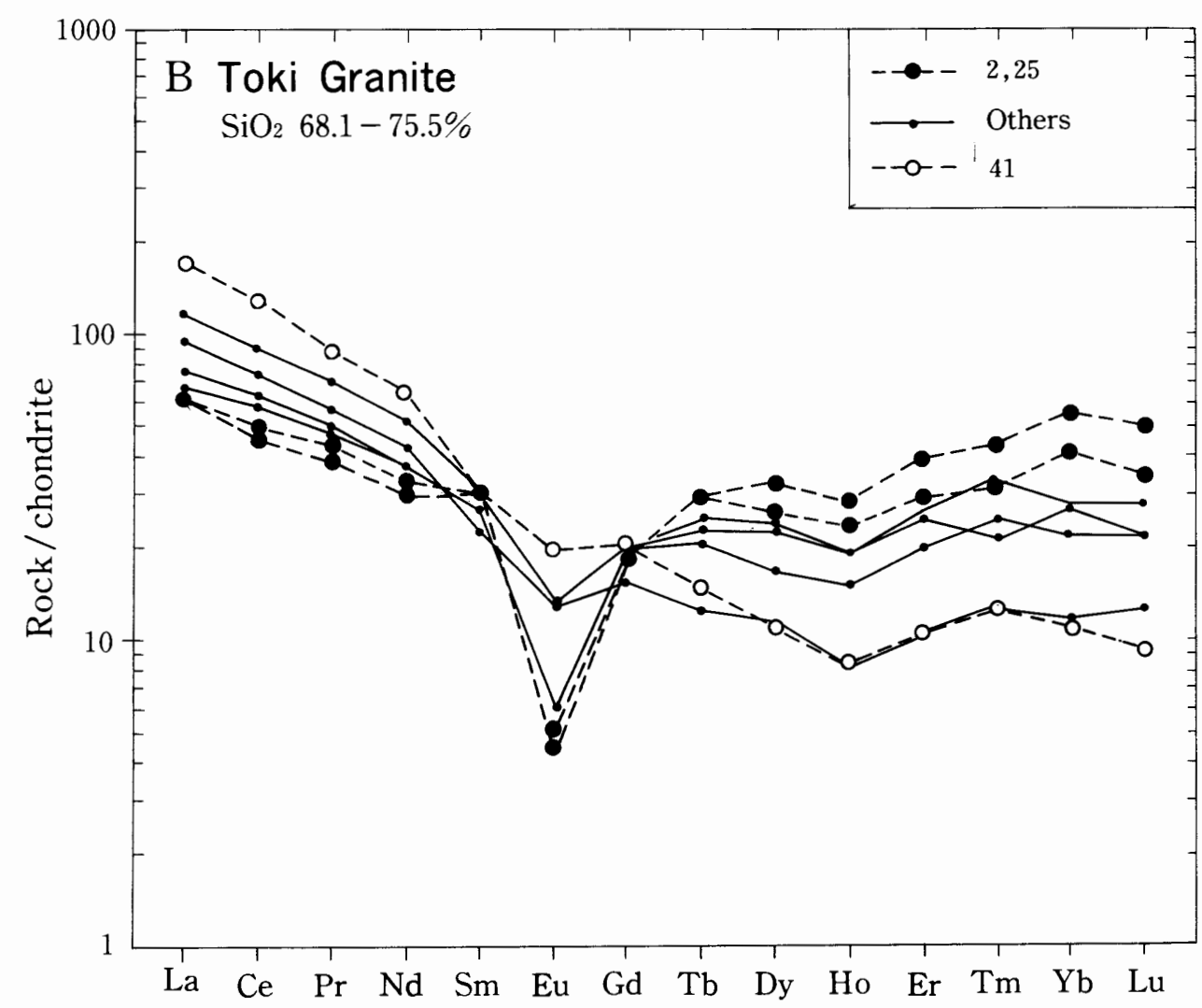

Fig. 8B Representative REE patterns of the Naegi and Toki granitoids, Chubu District.

fractionated than the Toki granite.

Similar variations to those observed between the Naegi and Toki granitoids, are also seen between the Toki and the Ryoke granitoids. Amongst the three granitoids, contents of $\mathrm{TiO}_{2}$, total $\mathrm{Fe}_{2} \mathrm{O}_{3}, \mathrm{MgO}$, $\mathrm{Al}_{2} \mathrm{O}_{3}, \mathrm{CaO}, \mathrm{Ba}, \mathrm{Sr}$ are highest, and those of $\mathrm{Na}_{2} \mathrm{O}$ (Fig.5), Rb, Th, U, REE are the lowest in the Ryoke granitoids. Two samples of the Ryoke granitoids have much lower Ba content (nos. 97, 139, Fig. 5), and may belong to xenolithic block of the older foliated granodiorites generated from different source materials.

REE patterns of the Naegi granite (Fig. 8A) are flat implying high concentration of HREE with strong Eu anomaly, similar to strongly fractionated I-type granite, e.g., the Caboniferous I-type granites of North Queenland (Champion and Chappell, 1992), and to A-type granites of the Lachlan Fold Belt (King et al., 1997) and Zhejiang Province of China (Charoy et al, 1987). Among eight samples studied, the chilled margin phase of "Nukame" granite (no. 211) is most depleted in $\mathrm{Eu}$ and highest in $\mathrm{Rb} / \mathrm{Sr}$ ratio (40.5, Appendix 3), implying plagioclase fractionation. In the Toki granite, hornblende-bearing phases (e.g., nos. 41, 38) and biotite-rich granite (no. 44) are rich in LREE and have no or weak negative Eu anomalies. Other Toki granite samples are rich in HREE and have similar REE pattern to those of the Naegi granite (Fig. 8B).

The Ryoke granitoids have a wide variety of REE patterns, because they include a variety of granitoids in the batholithic unit. Fine-grained biotite granite of stock size, which can be considered equivalent to the Naegi granite (Yamada et al., 1974), has a similar REE pattern to those of the Naegi granite (no. 70), while the other sample (no. 145) is more depleted in both LREE and HREE. The granitoids of nos. 110 and 114 are most depleted in HREE.

\section{Discussions}

\subsection{I type vs. A type}

F contents of the Naegi granite are the highest of the Japanese granitoids (Ishihara and Terashima, 1977b). Other elements with high concentration in the Naegi granite are known to be also enriched in A-type granitoids (Collins et al., 1982; Ishihara, 1988; King et al., 1997). Thus, the Naegi granite could possibly be an independent magma of A type. However, $\mathrm{Ga}$ is not as rich as $\mathrm{A}$-type granites in the continental regions, like Australia (Fig. 9) and China. As I type becomes strongly fractionated, F, Ga, Y, HREE etc also increase strongly (Champion and Chappell, 1992), such that they in part resemble A-types. Geologically, the Naegi granite occurs at northern margin of the calc-alkaline granitoids of I type. Similar granites are seen along the northern fringe of the Sanyo-Naegi Belt; e.g., biotite granites at Tanokami, Shiga Pref., the Kurashiki area of Okayama Pref. and the Iwakuni 


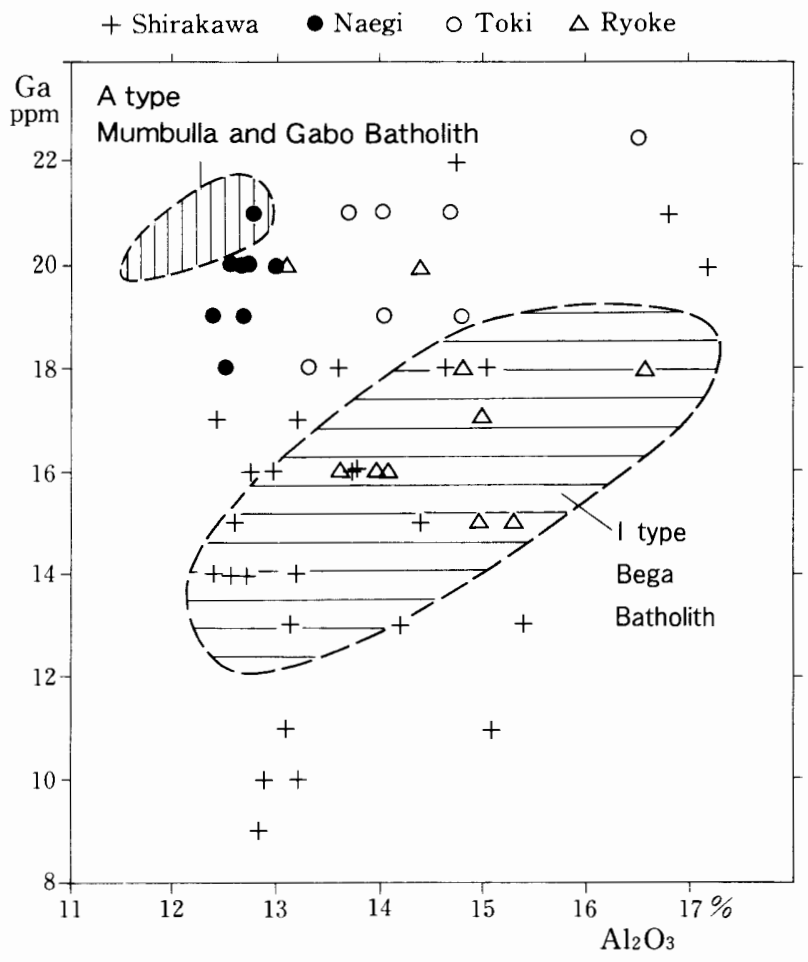

Fig. 9 Ga vs. $\mathrm{Al}_{2} \mathrm{O}_{3}$ diagram of the studied granitoids and Australian A-type (Mumbulla and Gabo) and I-type (Bega) granites from Collins et al. (1982).

area of Yamaguchi Pref. In the Kurashiki area, the granite occurs at margin of the so-called Hiroshima biotite granite, and the boundary of the two granites is unclear, suggesting that they are cogenetic. The Naegi and Toki granites have had a common I-type source but fractionated in different ways; the Naegi granite is most fractionated and emplaced in the highest level. Thus, it could be fractionated I type ilmenite series.

\subsection{Magnetite-series vs. Ilmenite-series Granitoids}

Magnetite-series granitoids of the Shirakawa area and ilmenite-series granitoids of the Naegi-Toki-Ryoke area have a wide range of silica contents (58 to $77 \%$ and 65 to $77 \%$, respectively). Chemical trends for most major elements are similar in those two granitoid series, except for the $\mathrm{Fe}_{2} \mathrm{O}_{3} / \mathrm{FeO}$ ratio and $\mathrm{Na}_{2} \mathrm{O}$ content (Ishihara and Terashima, 1977a). As mentioned previously, the Shirakawa granitoids are composed of two groups in terms of $\mathrm{Na}_{2} \mathrm{O}$ and $\mathrm{SiO}_{2}$ contents, and may have different source materials.

The Naegi-Toki granitoids have similar $\mathrm{SiO}_{2}$ content to the high silica Shirakawa granidoids, but are lower in $\mathrm{Na}_{2} \mathrm{O}$ and higher in $\mathrm{K}_{2} \mathrm{O}$. The Ryoke granitoids are much lower in $\mathrm{Na}_{2} \mathrm{O}$ content (Fig. 4). Given in relatively high ${ }^{87} \mathrm{Sr} /{ }^{86} \mathrm{Sr}$ initial ratio, these granitoids are considered to have been generated from different source materials within the continental crust. A $\mathrm{Na}_{2} \mathrm{O}$-rich and $\mathrm{K}_{2} \mathrm{O}$-poor character may be expected in intermediate meta-igneous rocks, while a potassic nature under a reducing atmosphere can be obtained from pelitic and arkossic sedimentary rocks of the source regions. This interpretation is supported by the fact that the magnetite-seires granitoids are mostly meta-aluminous $(\mathrm{A} / \mathrm{CNK}<1.0)$, while the ilmenite-series rocks are generally per-aluminous $(\mathrm{A} / \mathrm{CNK}>1.0)$.

Two series of the granitoids are also clearly separated by $\mathrm{Y}$ content. The contents are generally lower than $30 \mathrm{ppm}$ in the magnetite-series granitoids, but higher than $30 \mathrm{ppm}$ in the ilmenite-series rocks (Appendices 2, 3). The same is true on the HREE contents. $\mathrm{Y}$ and HREE elements are strongly partitioned to garnet, zircon, apatite and titanite, and moderately to hornblende (Pearce and Norry, 1979; Ogasawara, 1989). Thus, the depletion of these elements indicates existence of these minerals, especially of garnet, in the source region for the magnetite-series magmas.

The Hida metamorphic rocks are composed mostly of quartzo-feldspathic gneiss, basic gneiss and calcareous gneiss, associated with lesser amount of pelitic gneiss (Suzuki, 1977). Their bulk composition is a mafic to intermediate one rich in the ferromagnesian components, $\mathrm{CaO}$ and $\mathrm{Na}_{2} \mathrm{O}$ (Nozawa et al., 1975, 1981; Suzuki, 1975, 1977). These rocks are intruded by magnetite-series Triassic-Jurassic granodiorite and granite and lesser diorites. Their chemical characteristics correspond to those of the Shirakawa granitoids. Some older, gray granitoids occur close to the east of the Shirakawa granitoids. Low Bougeur anomalies are widely present in the Hida metamorphic terrane (Komazawa et al., 1999), indicating that these metamorphic and igneous or similar rocks continue to the depth. The high $\mathrm{Na}_{2} \mathrm{O}-$ low $\mathrm{SiO}_{2}$ and meta-aluminous initial magma and low $\mathrm{Na}_{2} \mathrm{O}-$ high $\mathrm{SiO}_{2}$ initial magma for Shirakawa granitoids could have generated from igneous rocks similar to the present constituents of the Hida metamorphic Belt.

The Mino sedimentary terrane, on the other hand, is an accretionary complex of Jurassic fore-arc sediments. Sandstone, shale, chert and their metamorphic equivalents occur dominantly associated with some limestones and ocean floor basalt (Nakai et al., 1985; Wakita, 2000). Their bulk composition is supposed to be dominantly sandstone, then shale and less chert, thus having high $\mathrm{K}_{2} \mathrm{O}$ and $\mathrm{Al}_{2} \mathrm{O}_{3}$ but low $\mathrm{Na}_{2} \mathrm{O}$ contents and a low $\mathrm{Fe}_{2} \mathrm{O}_{3} / \mathrm{FeO}$ ratio. These characteristics are also seen in the Naegi-Toki and Ryoke granitoids, implying that the accretionary complex continues to depth. The Ryoke granitoids, however, consist of both hornblende-biobite and biotite mineral asssemblages. Thus, some I-type components are necessary for the source region, which could have been brought as basaltic magmas (Ishihara, 2001). The studied granitoids are considered to reflect the chemical compositions of the immediate basement rocks they were found in. 


\section{Conclusions}

Magnetite-series granitoids of the Shirakawa area are divided into high $\mathrm{Na}_{2} \mathrm{O}$ and low $\mathrm{Na}_{2} \mathrm{O}$ groups. Each group appears to have its own magma source. Monzodiorite-granodiorite of the Shirakawa granitoids may have originated from mafic and intermediate igneous protoliths containing garnet. Similarly mafic enclaves and granodiorite of the high $\mathrm{Na}_{2} \mathrm{O}$ group were derived from mafic igneous protoliths. Biotite granites of low $\mathrm{Na}_{2} \mathrm{O}$ group were most likely derived from an igneous source of intermediate composition, similar to those of the Hida metamorphic belt.

The Naegi-Toki-Ryoke granitoids were generated from continental materials, most probably the sedimentary components of the Mino terrane, but also including some igneous-source components. The sedimentary/mafic igneous ratios of the source materials may be different between the Naegi-Toki granitic area and the Ryoke granitic area. The chemical difference between the Naegi and Toki granitoids may be attributed to the degree of fractionation and the depth of emplacement.

Acknowledgements: The chemical analyses of this work was done with guidance of Shigeko Togashi (XRF) and Noboru IMAI (ICP-MS) during Chengyu Wu stayed at the Geological Survey of Japan between 1992 and 1995 under the STA post-D. Sc. Fellowship. The authors acknowledge B.W. Chappell for his continued discussion on granite geneses and D. C. CHAMPION for his critical reviewing of the original manuscript.

\section{References}

Champion, D. C. and Chappell, B. W. (1992) Petrogenesis of felsic I-type granites: An example from northern Queensland. Trans. Royal Soc. Edingburgh: Earth Sci., 83, 115-126.

Chappell, B. W. (1999) Aluminium saturation in $\mathrm{I}^{-}$and S-type granites and the characterization of fractionated haplogranites. Lithos, 46, $535-551$.

Chappell, B. W. and White, A. J. R. (1992) Iand S-type granites in the Lachlan fold Belt. Trans. Royal Soc. Edingburgh: Earth Sci., 83, $1-26$.

Charoy, B., Couturie, J.P., Raimbault, L. and Liu, Y. (1987) The Suzhou granite complex (East China): Evolution from granite to biotitite with consequent $\mathrm{Zr}$ and REE mineralization. Abst. Intern. Sym. "Petrogenesis and Mineralizations of Granitoids”. Inst. Geochem. (Guiyang), 22-23.

Collins, W.J., Beams, S.D., White, A.J.R. and Chappell, B.W. (1982) Nature and origin of A-type granites with particular reference to southwestern Australia. Contrib. Mineral. Petrol., 80, 189-200.

Ishihara, S. (1971a) Major molybdenum deposits and related granitic rocks in Japan. Rept. Geol. Surv. Japan, no. 239, 178 p. (in Japanese with English abstract).

Ishihara, S. (1971b) Modal and chemical compositions of the granitic rocks related to the major molybdenum and tungsten deposits in the Inner Zone of Southwest Japan. Jour. Geol. Soc. Japan, 77, 441-452.

Ishihara, S. (1973) The Mo-W metallogenic provinces and the related granitic provinces. Mining Geol., 23, 13-32 (in Japanese with English abstract).

Ishihara, S. (1984) Granitoid series and Mo/W-Sn mineralization in East Asia. Rept. Geol. Surv. Japan, no. 263, 173-208.

Ishihara, S. (1988) A-type granite and REE ore deposits. Chishitsu Neres, no. 409, 6-24 (in Japanese).

Ishihara, S. (1990) The Inner Zone batholith vs. the Outer Zone batholith in Japan; Evaluation from their magnetic susceptibility. In M. Shimizu \& G. Gastil ed., Recent Advances in Concepts Concerning Zoned Plutons in Japan and Southern and Baja California. The Univ. Museum, Univ. Tokyo, Nature \& Culture, $2,21-34$.

Ishihara, S. (2001) Tectonic setting of S-type granitoids in Japan. Lithos (submitted).

Ishihara, S. and Terashima, S. (1977a) Chemical variation of the Cretaceous granitoids across southwestern Japan -Shirakawa-Toki-Okazaki transection - Jour. Geol. Soc. Japan, 83, 1-18.

Ishihara, S. and Terashima, S. (1977b) Chlorine and fluorine contents of granitoids as an indicator for base metal and tin mineralizations. Mining Geol., 27, 191-199.

Kawata, K. (1961) Explanatory text of the geological map of Japan. "Tsukechi". Scale 1:50,000, Geol. Surv. Japan. 69 p. (in Japanese with English abstract).

Koido, Y. and Yamada, N. (1999) Nohi Rhyolites. In Excursion Guidebook, 106th Ann. Mtg. Geol. Soc. Japan (Nagoya), 47-64 (in Japanese).

King, P.L., White, A.J.R., Chappell, B.W. and Allen, C.M. (1997) Characterization and origin of aluminous A-type granites from the Lachlan Fold Belt, southeastern Australia. Jour. Petrol. 38, 371-391.

Komazawa, M., Hiroshima, T., Ishihara, T., Murata, Y., Yamazaki, T., Joshima, M., Makino, M., Morijiri, R., Shichi, R., Kishimoto, K. and Kikawa, E. (1999) Gravity anomaly of Japan (Bouguer anonalies), Scale 
1:1,000,000, Geol. Surv. Japan. 14 p.

Koseki, K. and Matsubara, H. (1961) Uraniferous pegmatite deposits in Japan. In Natural Occurrence of Uranium in Japan, Pt. 1. Rept. Geol. Surv. Japan, no.190, 13-26 (in Japanese with English abstract).

Nakai. Y., Takeuchi, A., Suganuma, T., Ohta, S., Sakamoto, E., Yamamoto, N. and Uchida, Y. (1985) Physiography and geology of Okazaki city. History of Okazaki City, new edition. Nature 14, 209 p. (in Japanese).

Nozawa, T., Kawata, K. and Kawai, M. (1975) Geology of the Hida-Furukawa District. Quadrangle Series, Scale 1:50,000, Geol. Surv. Japan. 79 p.

Nozawa, T., Sakamoto, T., Kano, T. and Inazuki, T. (1981) Geology of the Shirokimine Deistrict. Quadrangle Series, Scale 1:50,000, Geol. Surv. Japan. 85 p.

Ogasawara, M. (1989) Geochemistry of rare-earth elements. Mining Geol., 39, 166-176 (in Japanese with English abstract).

Onishi, A., Matsuki, M. and Kobayashi, N. (1973) Geology of the Hirase molybdenum mine area, Gifu Prefecture. Mining Geol., 23, 119-136 (in Japanese with English abstract).

Pearce. J. A. and M. J. Norry (1979) Petrogenetic implications of $\mathrm{Ti}, \mathrm{Zr}, \mathrm{Y}$ and $\mathrm{Nb}$ variations in volcanic rocks. Contrib. Mineral. Petrol., 69, 33-47.

Sakamaki, Y., Hamachi, T. and Igarashi, T. (1961) Granitic rocks and related uraniferous ore deposits in Naegi District. In Natural Occurrence of Uranium in Japan pt. 1, Rept. Geol. Surv. Japan, no. 190, 56-68 (in Japanese with English abstract).

Shibata, K. and Ishihara, S. (1979) Rb-Sr whole-rock and $\mathrm{K}$-Ar mineral ages of granitic rocks in Japan. Geochem. J., 13, 113-119.

Suzuki, M. (1975) On the petrochemical character of the pelitic gneiss from the southwestern part in the Hida metamorphic belt, central Japan. Jour. Sci. Hiroshima Univ., Ser. C, 7 , 133-148.

Suzuki, M. (1977) Polymetamorphism in the Hida metamorphic belt, central Japan. Jour. Sci. Hiroshima Univ., Ser. C, 7, 217-296.
Suzuki, Y. and Ishihara, S. (1969) Modal compositions of granitic plutons of Toki-Okazaki region, central Japan. In Natural Occurrence of Uranium in Japan, Pt. 2, Rept. Geol. Surv. Japan, no. 232, 155-168 (in Japanese with English abstract).

Tuttle, O.F. and Bowen, N.L. (1958) Origin of the granite in the light of experimental studies in the system $\mathrm{NaAlSi}_{3} \mathrm{O}_{8}-\mathrm{KaAlSi}_{3} \mathrm{O}_{8}-\mathrm{SiO}_{2}-\mathrm{H}_{2} \mathrm{O}$. Geol. Soc. America, Mem. 74, 158 p.

Wakita, K. (2000) Melanges of the Mino terrane. Mem. Geol. Soc. Japan, no. 55,145-163 (in Japanese with English abstract).

Wu, C.-Y. and Ishihara, S. (1994) REE geochemistry of the southern Thailand granites. Jour. SE Asian Earth Sci., 10, 81-94.

Wu, C.-Y., Bai, G., Yuan, Z.-X., Nakajima, T. and Ishihara, S. (1993) Proterozoic metamorphic rock-hosted $\mathrm{Zr}, \mathrm{Y}$ and HREE mineralization in the Dabie Mountain area, central China. Intern. Geol. Review, 35, 898-919.

Yamada, N. (1977) Nohi Rhyolite and associated granitic rocks. In Yamada, N., Nozawa, T., Hayama, Y. and Yamada, T. ed. Mesozoic Felsic Igneous Activity and Related Metamorphism in Central Japan - from Nagoya to Toyama-. Guidebook Exc. 4, 33-60, Geol. Surv. Japan.

Yamada, N. (1989) Late Cretaceous Ena cauldron found in the southermost part of the Nohi rhyolitic mass, central Japan. Assoc. Geol. Collab. Japan, Mongraph no. 36, 21-33 (in Japanese with English abstract).

Yamada, N. and Nakai, Y. (1969) Geologic relations between the Nohi Rhyolites and the so-called Ryoke granites in central Japan. Mem. Geol. Soc. Japan, 4, 51-60 (in Japanese with English abstract).

Yamada, N., Katada, M., Hayama, Y., Yamada, T., Nakai, Y., Kutsukake, T. Suwa, K. and Miyagawa, K. (1974) Geological map of the Ryoke belt, central Japan. Miscel. Map Ser. 18, Geol. Surv. Japan.

Received July 16, 2001

Accepted December 20, 2001 
Appendix 1 Major and trace element contents of the Nohi Rhyolites from the Shirakawa area.

\begin{tabular}{|c|c|c|c|c|c|c|c|c|c|c|c|}
\hline \multirow{2}{*}{$\begin{array}{l}\text { Location } \\
\text { Sample No. }\end{array}$} & \multicolumn{3}{|c|}{ Fresh } & \multicolumn{3}{|l|}{ Rhyolite } & \multicolumn{3}{|c|}{ Altered } & \multicolumn{2}{|l|}{ Rhyolite } \\
\hline & $67 \mathrm{RS}-60$ & 67RS-64 & $67 \mathrm{RS}-65$ & $67 \mathrm{RS}-66$ & $67 \mathrm{RS}-67$ & $67 \mathrm{RS}-78$ & $67 \mathrm{RS}-71$ & $67 \mathrm{RS}-72$ & $67 \mathrm{RS}-94$ & 67RS-95 & $67 \mathrm{RS}-161$ \\
\hline$\overline{\mathrm{SiO}_{2}(\%)}$ & 58.57 & 72.93 & 75.20 & 74.81 & 72.09 & 68.39 & 72.68 & 75.33 & 75.61 & 74.44 & 76.62 \\
\hline $\mathrm{TiO}_{2}$ & 0.92 & 0.21 & 0.20 & 0.14 & 0.23 & 0.38 & 0.10 & 0.08 & 0.09 & 0.10 & 0.10 \\
\hline $\mathrm{Al}_{2} \mathrm{O}_{3}$ & 16.52 & 14.66 & 13.17 & 12.78 & 13.88 & 14.68 & 13.61 & 12.77 & 12.36 & 13.33 & 14.24 \\
\hline $\mathrm{TFe}_{2} \mathrm{O}_{3}$ & 6.96 & 2.40 & 1.90 & 1.70 & 2.53 & 2.98 & 1.57 & 1.34 & 1.81 & 2.19 & 0.76 \\
\hline $\mathrm{MnO}$ & 0.14 & 0.06 & 0.04 & 0.04 & 0.08 & 0.08 & 0.10 & 0.06 & 0.07 & 0.04 & 0.02 \\
\hline $\mathrm{MgO}$ & 2.74 & 0.49 & 0.30 & 0.15 & 0.59 & 0.88 & 0.02 & 0.01 & 0.06 & 0.03 & 0.03 \\
\hline $\mathrm{CaO}$ & 6.40 & 1.54 & 1.05 & 1.00 & 1.56 & 2.46 & 0.58 & 0.34 & 0.41 & 0.24 & 0.07 \\
\hline $\mathrm{Na}_{2} \mathrm{O}$ & 2.92 & 2.66 & 1.95 & 3.39 & 3.43 & 4.05 & 4.02 & 3.58 & 3.21 & 2.17 & 0.92 \\
\hline $\mathrm{K}_{2} \mathrm{O}$ & 3.34 & 4.26 & 4.77 & 4.28 & 3.98 & 3.63 & 5.13 & 5.10 & 4.46 & 5.83 & 5.59 \\
\hline $\mathrm{P}_{2} \mathrm{O}_{5}$ & 0.30 & 0.04 & 0.04 & 0.03 & 0.05 & 0.10 & 0.01 & 0.01 & 0.01 & 0.02 & 0.02 \\
\hline LOI & 1.19 & 1.25 & 1.11 & 0.78 & 0.88 & 0.69 & 1.26 & 0.95 & 1.11 & 1.02 & 0.65 \\
\hline Total & 100.00 & 100.50 & 99.73 & 99.11 & 99.30 & 98.32 & 99.08 & 99.57 & 99.20 & 99.40 & 99.02 \\
\hline $\mathrm{V}(\mathrm{ppm})$ & 178 & 20 & 13 & 6 & 21 & 37 & 3 & NA & NA & NA & NA \\
\hline $\mathrm{Cr}$ & 92 & 39 & 38 & 45 & 33 & 24 & 22 & NA & NA & NA & NA \\
\hline $\mathrm{Ni}$ & 16 & 11 & 11 & 8 & 11 & 6 & 8 & $\mathrm{NA}$ & NA & $\mathrm{NA}$ & NA \\
\hline $\mathrm{Zn}$ & 127 & 39 & 28 & 37 & 151 & 47 & 34 & 25 & 53 & 211 & 49 \\
\hline $\mathrm{Ga}(\mathrm{XRF})$ & 20 & 16 & 17 & 22 & 19 & 17 & 16 & 13 & 19 & 18 & 22 \\
\hline $\mathrm{Rb} \quad(\mathrm{XRF})$ & 108 & 170 & 179 & 139 & 140 & 118 & 169 & 182 & 156 & 246 & 270 \\
\hline $\mathrm{Sr}$ (XRF) & 446 & 142 & 120 & 119 & 189 & 255 & 42 & 26 & 22 & 25 & 24 \\
\hline $\mathrm{Y}(\mathrm{XRF})$ & 26.7 & 39.4 & 41.1 & 28.8 & 28.7 & 24.4 & 35.7 & 32.4 & 33.4 & 38.4 & 37.6 \\
\hline $\mathrm{Zr} \quad(\mathrm{XRF})$ & 174 & 172 & 165 & 149 & 148 & 162 & 235 & 210 & 192 & 232 & 230 \\
\hline $\mathrm{Nb}$ & 10 & 12 & 13 & 12 & 12 & 11 & 15 & 12 & 14 & 15 & 16 \\
\hline Sn & 3.4 & 4.2 & 3.7 & 2.1 & 4.9 & 1.2 & 3.9 & 2.2 & 3.3 & 3.3 & 3.7 \\
\hline Cs & 7.6 & 10.4 & 8.5 & 5.0 & 6.4 & 2.5 & 1.8 & 2.2 & 2.1 & 6.2 & 8.7 \\
\hline $\mathrm{Ba} \quad(\mathrm{XRF})$ & 934 & 562 & 674 & 636 & 658 & 789 & 151 & 108 & 112 & 161 & 188 \\
\hline $\mathrm{La}$ & 25 & 41 & 37 & 31 & 31 & 33 & 59 & 44 & 46 & 61 & 59 \\
\hline $\mathrm{Ce}$ & 52 & 80 & 72 & 60 & 62 & 65 & 112 & 88 & 95 & 115 & 118 \\
\hline $\operatorname{Pr}$ & 6.5 & 9.4 & 9.0 & 6.5 & 7.2 & 7.2 & 12.6 & 10.1 & 10.7 & 13.0 & 13.7 \\
\hline $\mathrm{Nd}$ & 25 & 34 & 32 & 23 & 26 & 26 & 47 & 38 & 38 & 46 & 49 \\
\hline Sm & 4.5 & 7.6 & 6.9 & 4.6 & 5.2 & 4.5 & 8.7 & 8.6 & 6.7 & 7.0 & 7.8 \\
\hline $\mathrm{Eu}$ & 1.33 & 0.77 & 0.87 & 0.54 & 0.57 & 0.95 & 0.41 & 0.30 & 0.20 & 0.52 & 0.29 \\
\hline $\mathrm{Gd}$ & 4.2 & 6.9 & 7.0 & 4.4 & 5.1 & 3.7 & 7.0 & 6.8 & 5.9 & 6.8 & 7.2 \\
\hline $\mathrm{Tb}$ & 0.7 & 0.9 & 1.1 & 0.6 & 0.7 & 0.6 & 1.0 & 1.0 & 1.0 & 1.2 & 1.1 \\
\hline Dy & 3.1 & 6.2 & 6.4 & 3.5 & 4.3 & 3.7 & 6.4 & 5.8 & 6.0 & 6.4 & 6.6 \\
\hline Ho & 0.7 & 1.1 & 1.1 & 0.7 & 0.7 & 0.7 & 0.9 & 1.0 & 1.0 & 1.0 & 1.1 \\
\hline Er & 2.4 & 4.5 & 4.9 & 2.9 & 3.3 & 2.0 & 4.0 & 3.4 & 2.7 & 3.0 & 3.2 \\
\hline$T_{m}$ & 0.5 & 0.9 & 0.9 & 0.5 & 0.5 & 0.4 & 0.7 & 0.7 & 0.6 & 0.6 & 0.7 \\
\hline $\mathrm{Yb}$ & 2.0 & 4.5 & 2.7 & 2.2 & 2.7 & 2.8 & 3.3 & 4.8 & 3.8 & 3.7 & 4.3 \\
\hline $\mathrm{Lu}$ & 0.3 & 0.6 & 0.8 & 0.5 & 0.7 & 0.4 & 0.8 & 0.6 & 0.5 & 0.4 & 0.6 \\
\hline $\mathrm{Hf}$ & 4.5 & 5.3 & 5.2 & 4.2 & 4.3 & 4.9 & 6.4 & 8.0 & 5.8 & 7.3 & 7.4 \\
\hline Тa & 0.7 & 1.5 & 1.1 & 0.9 & 0.9 & 0.9 & 1.0 & 1.3 & 1.2 & 1.3 & 1.5 \\
\hline $\mathrm{Pb}$ & 23 & 20 & 22 & 18 & 47 & 17 & 46 & 27 & 24 & 27 & 27 \\
\hline Th & 9.7 & 17.7 & 16.8 & 12.7 & 14.5 & 12.0 & 19.0 & 18.0 & 17.7 & 17.4 & 19.9 \\
\hline $\mathrm{U}$ & 2.0 & 3.8 & 3.9 & 2.8 & 3.1 & 2.3 & 4.6 & 3.4 & 3.8 & 3.6 & 3.9 \\
\hline REE & 154.5 & 238.0 & 224.1 & 169.4 & 178.8 & 175.9 & 298.8 & 246.1 & 251.4 & 303.3 & 309.4 \\
\hline $\mathrm{Sm} / \mathrm{Nd}$ & 0.18 & 0.22 & 0.22 & 0.20 & 0.20 & 0.17 & 0.19 & 0.22 & 0.18 & 0.15 & 0.16 \\
\hline $\mathrm{Rb} / \mathrm{Sr}$ & 0.2 & 1.2 & 1.5 & 1.2 & 0.7 & 0.5 & 4.0 & 7.0 & 7.1 & 9.8 & 11.3 \\
\hline $\mathrm{Th} / \mathrm{U}$ & 4.8 & 4.7 & 4.3 & 4.5 & 4.8 & 5.3 & 4.1 & 5.2 & 4.6 & 4.8 & 5.2 \\
\hline $10000 \mathrm{Ga} / \mathrm{Al}$ & 2.34 & 2.07 & 2.43 & 3.18 & 2.54 & 2.13 & 2.28 & 1.93 & 2.86 & 2.58 & 2.92 \\
\hline $\mathrm{Y} / \mathrm{Nb}$ & 2.8 & 3.2 & 3.2 & 2.5 & 2.5 & 2.2 & 2.4 & 2.8 & 2.3 & 2.6 & 2.4 \\
\hline $\mathrm{Nb} / \mathrm{Ta}$ & 14.5 & 8.6 & 11.6 & 12.4 & 12.9 & 12.6 & 14.7 & 8.7 & 12.0 & 11.6 & 10.6 \\
\hline $\mathrm{Zr} / \mathrm{Hf}$ & 39.0 & 32.5 & 31.6 & 35.7 & 34.3 & 33.3 & 36.6 & 26.4 & 33.1 & 32.0 & 31.0 \\
\hline $\mathrm{A} / \mathrm{CNK}$ & 0.82 & 1.24 & 1.28 & 1.06 & 1.09 & 0.97 & 1.03 & 1.06 & 1.14 & 1.29 & 1.85 \\
\hline $\mathrm{TFeO} / \mathrm{MgO}$ & 2.3 & 4.5 & 5.8 & 10.0 & 3.9 & 3.1 & 71.4 & 121.8 & 27.4 & 79.6 & 23.0 \\
\hline
\end{tabular}


Genesis of Late Cretaceous-Paleogene Granitoids (ISHIHARA and $W_{U}$ )

Appendix 2 Major and trace element contents of the Shirakawa granitoids.

\begin{tabular}{|c|c|c|c|c|c|c|c|c|c|c|}
\hline Location & & & North & Hatogaya & & & South & Hatogaya & & Aradani \\
\hline Sample No. & $67 \mathrm{RS}-86$ & 67RS-87 & 67RS-88 & $67 \mathrm{RS}-89$ & 67RS-91 & 67RS-92 & $67 \mathrm{RS}-80$ & 67RS-93 & 67RS-83 & 67RS-84 \\
\hline $\mathrm{SiO}_{2}(\%)$ & 62.96 & 72.78 & 59.84 & 73.73 & 76.73 & 77.17 & 75.56 & 77.00 & 70.80 & 70.26 \\
\hline $\mathrm{TiO}_{2}$ & 0.49 & 0.24 & 0.84 & 0.21 & 0.07 & 0.06 & 0.14 & 0.09 & 0.33 & 0.33 \\
\hline $\mathrm{Al}_{2} \mathrm{O}_{3}$ & 17.18 & 13.72 & 16.80 & 13.68 & 12.66 & 12.71 & 13.20 & 12.63 & 14.65 & 14.72 \\
\hline $\mathrm{TFe}_{2} \mathrm{O}_{3}$ & 4.62 & 1.85 & 6.18 & 1.64 & 0.89 & 0.87 & 1.33 & 1.07 & 2.64 & 2.55 \\
\hline $\mathrm{MnO}$ & 0.12 & 0.04 & 0.23 & 0.05 & 0.04 & 0.05 & 0.05 & 0.05 & 0.10 & 0.08 \\
\hline $\mathrm{MgO}$ & 1.33 & 0.46 & 2.37 & 0.47 & 0.11 & 0.12 & 0.23 & 0.17 & 0.66 & 0.74 \\
\hline $\mathrm{CaO}$ & 3.87 & 1.60 & 5.30 & 1.27 & 0.55 & 0.46 & 1.02 & 0.64 & 1.95 & 2.26 \\
\hline $\mathrm{Na}_{2} \mathrm{O}$ & 4.64 & 3.67 & 4.77 & 4.01 & 3.67 & 4.02 & 3.86 & 3.58 & 4.68 & 4.56 \\
\hline $\mathrm{K}_{2} \mathrm{O}$ & 2.82 & 4.11 & 2.09 & 4.09 & 4.82 & 4.31 & 4.19 & 4.52 & 3.35 & 3.33 \\
\hline $\mathrm{P}_{2} \mathrm{O}_{5}$ & 0.24 & 0.07 & 0.27 & 0.07 & 0.01 & 0.01 & 0.04 & 0.02 & 0.10 & 0.11 \\
\hline LOI & 1.18 & 0.63 & 1.04 & 0.92 & 0.19 & 0.36 & 0.40 & 0.51 & 0.38 & 0.52 \\
\hline Total & 99.45 & 99.17 & 99.73 & 100.14 & 99.74 & 100.14 & 100.02 & 100.28 & 99.64 & 99.46 \\
\hline$V(\mathrm{ppm})$ & 46 & 22 & 119 & 13 & 3 & $\langle 2$ & 9 & 5 & 23 & 29 \\
\hline $\mathrm{Cr}$ & $<4$ & 16 & 20 & $<4$ & 6 & 7 & 18 & 17 & $<4$ & 27 \\
\hline $\mathrm{Ni}$ & 6 & 4 & 8 & 2 & 6 & 6 & 7 & 6 & 2 & 7 \\
\hline $\mathrm{Zn}$ & 56 & 32 & 85 & 26 & 28 & 14 & 30 & 27 & 62 & 67 \\
\hline Ga (XRF) & 20 & 16 & 21 & 16 & 14 & 16 & 17 & 15 & 18 & 21 \\
\hline $\mathrm{Rb} \quad(\mathrm{XRF})$ & 75 & 109 & 73 & 116 & 158 & 200 & 132 & 168 & 109 & 104 \\
\hline $\mathrm{Sr}(\mathrm{XRF})$ & 492 & 224 & 427 & 188 & 34 & 23 & 102 & 67 & 207 & 246 \\
\hline $\mathrm{Y}(\mathrm{XRF})$ & 27.9 & 9.0 & 29.4 & 11.5 & 20.3 & 32.5 & 23.2 & 19.5 & 26.5 & 20.3 \\
\hline $\mathrm{Zr} \quad(\mathrm{XRF})$ & 267 & 140 & 169 & 139 & 90 & 75 & 103 & 87 & 183 & 171 \\
\hline $\mathrm{Nb}$ & 8 & 5 & 12 & 6 & 9 & 13 & 12 & 10 & 12 & 9 \\
\hline Sn & 2.1 & 0.6 & 2.7 & 0.5 & 1.9 & 2.4 & 0.9 & 1.9 & 2.3 & 1.4 \\
\hline $\mathrm{Cs}$ & 1.1 & 0.5 & 0.8 & 0.9 & 1.7 & 3.1 & 1.0 & 1.3 & 1.4 & 1.1 \\
\hline $\mathrm{Ba}$ (XRF) & 747 & 876 & 466 & 772 & 200 & 86 & 471 & 378 & 726 & 747 \\
\hline $\mathrm{La}$ & 38 & 39 & 32 & 34 & 21 & 21 & 24 & 21 & 44 & 29 \\
\hline $\mathrm{Ce}$ & 75 & 71 & 63 & 64 & 45 & 46 & 48 & 43 & 82 & 54 \\
\hline $\operatorname{Pr}$ & 8.8 & 7.4 & 8.1 & 7.3 & 5.0 & 5.8 & 5.9 & 5.3 & 9.3 & 6.3 \\
\hline $\mathrm{Nd}$ & 34 & 24 & 32 & 24 & 19 & 22 & 20 & 18 & 30 & 21 \\
\hline Sm & 6.2 & 3.5 & 6.5 & 3.8 & 3.7 & 5.2 & 3.8 & 3.2 & 5.4 & 3.6 \\
\hline Eu & 1.22 & 0.71 & 1.22 & 0.75 & 0.32 & 0.13 & 0.60 & 0.33 & 1.08 & 1.04 \\
\hline Gd & 4.8 & 2.9 & 5.5 & 2.5 & 2.7 & 5.4 & 3.2 & 2.8 & 4.2 & 3.2 \\
\hline $\mathrm{Tb}$ & 0.6 & 0.3 & 0.9 & 0.3 & 0.5 & 0.8 & 0.5 & 0.5 & 0.6 & 0.5 \\
\hline Dy & 4.4 & 1.6 & 4.9 & 1.8 & 3.2 & 5.2 & 3.4 & 3.1 & 4.1 & 2.6 \\
\hline Ho & 0.8 & 0.2 & 1.0 & 0.3 & 0.6 & 1.1 & 0.6 & 0.5 & 0.7 & 0.5 \\
\hline Er & 2.3 & 0.9 & 2.2 & 1.4 & 1.9 & 2.9 & 2.8 & 2.1 & 2.4 & 1.5 \\
\hline $\mathrm{Tm}$ & 0.5 & 0.2 & 0.6 & 0.2 & 0.4 & 0.7 & 0.4 & 0.4 & 0.4 & 0.3 \\
\hline $\mathrm{Yb}$ & 2.5 & 0.9 & 2.0 & 1.5 & 2.3 & 3.0 & 2.5 & 1.9 & 2.5 & 1.8 \\
\hline $\mathrm{Lu}$ & 0.3 & 0.2 & 0.3 & 0.2 & 0.3 & 0.6 & 0.4 & 0.3 & 0.5 & 0.3 \\
\hline $\mathrm{Hf}$ & 6.7 & 3.0 & 4.7 & 4.0 & 2.9 & 3.8 & 3.8 & 2.6 & 5.7 & 4.7 \\
\hline $\mathrm{Ta}$ & 0.6 & 0.4 & 0.7 & 0.6 & 1.2 & 2.1 & 0.9 & 0.9 & 0.7 & 0.5 \\
\hline $\mathrm{Pb}$ & 6 & 8 & 5 & 8 & 17 & 15 & 15 & 17 & 13 & 12 \\
\hline Th & 6.7 & 8.4 & 5.0 & 11.0 & 15.4 & 25.6 & 16.2 & 16.9 & 11.7 & 8.9 \\
\hline$\underline{\mathrm{U}}$ & 1.9 & 1.2 & 1.5 & 2.4 & 3.4 & 4.8 & 3.4 & 2.7 & 2.2 & 1.6 \\
\hline REE & 206.9 & 162.0 & 189.4 & 153.5 & 126.0 & 151.6 & 139.2 & 121.7 & 214.0 & 146.8 \\
\hline $\mathrm{Sm} / \mathrm{Nd}$ & 0.18 & 0.14 & 0.21 & 0.16 & 0.19 & 0.24 & 0.19 & 0.18 & 0.18 & 0.17 \\
\hline $\mathrm{Rb} / \mathrm{Sr}$ & 0.2 & 0.5 & 0.2 & 0.6 & 4.6 & 8.7 & 1.3 & 2.5 & 0.5 & 0.4 \\
\hline $\mathrm{Th} / \mathrm{U}$ & 3.5 & 7.1 & 3.3 & 4.6 & 4.5 & 5.4 & 4.8 & 6.3 & 5.4 & 5.7 \\
\hline $10000 \mathrm{Ga} / \mathrm{Al}$ & 2.20 & 2.16 & 2.41 & 2.18 & 2.07 & 2.39 & 2.47 & 2.29 & 2.29 & 2.70 \\
\hline $\mathrm{Y} / \mathrm{Nb}$ & 3.3 & 1.9 & 2.5 & 1.9 & 2.3 & 2.4 & 1.9 & 1.9 & 2.3 & 2.3 \\
\hline $\mathrm{Nb} / \mathrm{Ta}$ & 14.6 & 12.1 & 17.4 & 9.6 & 7.6 & 6.3 & 13.6 & 11.8 & 15.6 & 17.3 \\
\hline $\mathrm{Zr} / \mathrm{Hf}$ & 40.0 & 46.5 & 35.9 & 34.4 & 31.5 & 19.6 & 27.0 & 32.8 & 32.0 & 36.8 \\
\hline $\mathrm{A} / \mathrm{CNK}$ & 0.97 & 1.02 & 0.85 & 1.03 & 1.03 & 1.05 & 1.04 & 1.06 & 0.99 & 0.97 \\
\hline $\mathrm{TFeO} / \mathrm{MgO}$ & 3.2 & 3.7 & 2.4 & 3.2 & 7.4 & 6.6 & 5.3 & 5.7 & 3.6 & 3.1 \\
\hline
\end{tabular}


Appendix 2 Continued.

\begin{tabular}{|c|c|c|c|c|c|c|c|c|c|c|}
\hline \multirow{2}{*}{$\begin{array}{l}\text { Location } \\
\text { Sample No. }\end{array}$} & \multicolumn{9}{|c|}{ Hirase } & \multirow[b]{2}{*}{ 67RS-76 } \\
\hline & 67RS-115 & 66RS-2 & $66 \mathrm{RS}-7$ & $66 \mathrm{RS}-9$ & 67RS-119 & $67 \mathrm{RS}-123$ & $66 \mathrm{RS}-8$ & $66 \mathrm{RS}-13$ & 67RS-75 & \\
\hline $\mathrm{SiO}_{2}(\%)$ & 71.04 & 76.70 & 75.90 & 75.37 & 77.34 & 74.59 & 71.75 & 74.96 & 75.07 & 76.32 \\
\hline $\mathrm{TiO}_{2}$ & 0.27 & 0.10 & 0.10 & 0.11 & 0.05 & 0.14 & 0.24 & 0.17 & 0.17 & 0.12 \\
\hline $\mathrm{Al}_{2} \mathrm{O}_{3}$ & 14.39 & 12.37 & 12.43 & 12.55 & 12.57 & 12.91 & 14.21 & 13.10 & 13.14 & 12.93 \\
\hline $\mathrm{TFe}_{2} \mathrm{O}_{3}$ & 2.26 & 0.76 & 0.83 & 1.14 & 0.74 & 1.36 & 1.91 & 1.24 & 1.50 & 1.23 \\
\hline $\mathrm{MnO}$ & 0.09 & 0.04 & 0.05 & 0.06 & 0.03 & 0.06 & 0.08 & 0.06 & 0.06 & 0.06 \\
\hline $\mathrm{MgO}$ & 0.64 & 0.11 & 0.17 & 0.10 & 0.03 & 0.26 & 0.53 & 0.36 & 0.29 & 0.21 \\
\hline $\mathrm{CaO}$ & 1.90 & 0.74 & 0.74 & 0.77 & 0.54 & 0.91 & 2.01 & 1.05 & 0.93 & 0.84 \\
\hline $\mathrm{Na}_{2} \mathrm{O}$ & 4.48 & 3.57 & 3.63 & 3.89 & 3.70 & 3.86 & 4.49 & 3.83 & 3.86 & 3.80 \\
\hline $\mathrm{K}_{2} \mathrm{O}$ & 3.32 & 4.44 & 4.58 & 4.33 & 4.81 & 4.22 & 3.27 & 3.95 & 4.07 & 4.28 \\
\hline $\mathrm{P}_{2} \mathrm{O}_{5}$ & 0.08 & 0.02 & 0.02 & 0.03 & 0.01 & 0.03 & 0.07 & 0.05 & 0.05 & 0.02 \\
\hline LOI & 0.92 & 0.66 & 0.72 & 0.86 & 0.38 & 1.23 & 0.89 & 0.56 & 0.42 & 0.48 \\
\hline Total & 99.40 & 99.51 & 99.17 & 99.21 & 100.20 & 99.57 & 99.45 & 99.33 & 99.56 & 100.29 \\
\hline $\mathrm{V}(\mathrm{ppm})$ & 17 & 3 & 4 & 7 & $<2$ & 7 & 16 & 8 & 9 & 6 \\
\hline $\mathrm{Cr}$ & 24 & 23 & 22 & 30 & 23 & 29 & 18 & 14 & 9 & 7 \\
\hline $\mathrm{Ni}$ & 6 & 5 & 6 & 6 & 7 & 6 & 4 & 5 & 3 & 4 \\
\hline $\mathrm{Zn}$ & 35 & 15 & 12 & 23 & 13 & 18 & 25 & 14 & 34 & 23 \\
\hline Ga (XRF) & 15 & 17 & 14 & 14 & 9 & 10 & 13 & 11 & 10 & 16 \\
\hline $\mathrm{Rb} \quad(\mathrm{XRF})$ & 127 & 141 & 150 & 132 & 143 & 130 & 131 & 132 & 121 & 161 \\
\hline $\mathrm{Sr}(\mathrm{XRF})$ & 211 & 71 & 66 & 80 & 28 & 97 & 215 & 133 & 120 & 94 \\
\hline $\mathrm{Y}(\mathrm{XRF})$ & 25.2 & 23.1 & 21.9 & 15.4 & 17.9 & 19.8 & 17.9 & 20.1 & 22.7 & 23.4 \\
\hline $\mathrm{Zr}$ (XRF) & 148 & 84 & 96 & 110 & 56 & 102 & 136 & 112 & 112 & 88 \\
\hline $\mathrm{Nb}$ & 5 & 17 & 12 & 7 & 9 & 9 & 8 & 9 & 9 & 5 \\
\hline Sn & 1.3 & 1.6 & 1.1 & 0.8 & 1.6 & 1.2 & 1.5 & 1.2 & 0.9 & 1.6 \\
\hline $\mathrm{Cs}$ & 1.9 & 0.9 & 1.0 & 1.4 & 1.5 & 1.5 & 1.7 & 1.2 & 0.8 & 3.7 \\
\hline $\mathrm{Ba}$ (XRF) & 602 & 474 & 558 & 555 & 88 & 582 & 583 & 589 & 607 & 524 \\
\hline $\mathrm{La}$ & 26 & 29 & 27 & 30 & 16 & 33 & 28 & 36 & 30 & 22 \\
\hline $\mathrm{Ce}$ & 51 & 55 & 54 & 60 & 37 & 67 & 56 & 72 & 54 & 46 \\
\hline $\operatorname{Pr}$ & 6.0 & 6.5 & 6.2 & 6.6 & 4.6 & 7.8 & 6.8 & 8.3 & 7.0 & 5.4 \\
\hline $\mathrm{Nd}$ & 20 & 21 & 20 & 21 & 17 & 25 & 24 & 29 & 25 & 19 \\
\hline $\mathrm{Sm}$ & 4.2 & 3.8 & 3.5 & 3.2 & 3.2 & 5.1 & 4.6 & 4.6 & 4.6 & 3.9 \\
\hline $\mathrm{Eu}$ & 0.89 & 0.53 & 0.49 & 0.50 & 0.39 & 0.63 & 0.82 & 0.58 & 0.64 & 0.52 \\
\hline $\mathrm{Gd}$ & 3.7 & 3.1 & 3.2 & 3.0 & 2.4 & 4.3 & 3.7 & 3.6 & 4.1 & 3.5 \\
\hline $\mathrm{Tb}$ & 0.7 & 0.5 & 0.5 & 0.4 & 0.6 & 0.8 & 0.6 & 0.7 & 0.7 & 0.6 \\
\hline Dy & 3.3 & 3.9 & 3.3 & 2.3 & 3.4 & 3.9 & 3.4 & 3.6 & 4.0 & 3.3 \\
\hline Ho & 0.7 & 0.7 & 0.6 & 0.4 & 0.6 & 0.6 & 0.7 & 0.7 & 0.7 & 0.7 \\
\hline $\mathrm{Er}$ & 2.2 & 3.1 & 2.2 & 1.6 & 2.6 & 2.5 & 2.0 & 2.3 & 2.9 & 2.7 \\
\hline$T_{m}$ & 0.3 & 0.4 & 0.5 & 0.2 & 0.4 & 0.4 & 0.3 & 0.4 & 0.5 & 0.4 \\
\hline $\mathrm{Yb}$ & 2.8 & 3.0 & 2.4 & 1.4 & 2.4 & 2.3 & 2.4 & 2.6 & 2.5 & 2.8 \\
\hline $\mathrm{Lu}$ & 0.4 & 0.5 & 0.4 & 0.3 & 0.3 & 0.4 & 0.3 & 0.4 & 0.4 & 0.4 \\
\hline Hf & 4.6 & 2.9 & 3.3 & 3.5 & 2.2 & 3.9 & 4.3 & 4.5 & 4.1 & 3.2 \\
\hline Ta & 0.5 & 1.3 & 1.1 & 0.6 & 1.1 & 1.2 & 0.8 & 1.1 & 1.1 & 0.6 \\
\hline $\mathrm{Pb}$ & 10 & 14 & 16 & 16 & 20 & 13 & 12 & 13 & 13 & 14 \\
\hline $\mathrm{Th}$ & 9.7 & 11.9 & 14.2 & 10.6 & 12.8 & 13.7 & 10.2 & 13.4 & 13.7 & 12.8 \\
\hline$\underline{U}$ & 2.1 & 2.9 & 2.9 & 2.6 & 2.9 & 2.5 & 2.1 & 2.5 & 2.4 & 3.9 \\
\hline REE & 147.3 & 154.7 & 146.9 & 146.9 & 108.8 & 173.4 & 151.5 & 183.9 & 159.8 & 134.9 \\
\hline $\mathrm{Sm} / \mathrm{Nd}$ & 0.21 & 0.18 & 0.17 & 0.15 & 0.19 & 0.20 & 0.19 & 0.16 & 0.19 & 0.20 \\
\hline $\mathrm{Rb} / \mathrm{Sr}$ & 0.6 & 2.0 & 2.3 & 1.7 & 5.1 & 1.3 & 0.6 & 1.0 & 1.0 & 1.7 \\
\hline $\mathrm{Th} / \mathrm{U}$ & 4.7 & 4.1 & 4.9 & 4.0 & 4.5 & 5.5 & 5.0 & 5.3 & 5.7 & 3.3 \\
\hline $10000 \mathrm{Ga} / \mathrm{Al}$ & 2.01 & 2.52 & 2.16 & 2.03 & 1.40 & 1.47 & 1.77 & 1.61 & 1.50 & 2.26 \\
\hline $\mathrm{Y} / \mathrm{Nb}$ & 5.2 & 1.4 & 1.8 & 2.3 & 2.1 & 2.3 & 2.2 & 2.3 & 2.6 & 4.3 \\
\hline $\mathrm{Nb} / \mathrm{Ta}$ & 10.6 & 13.4 & 10.9 & 11.8 & 7.9 & 7.2 & 9.9 & 8.0 & 7.6 & 8.8 \\
\hline $\mathrm{Zr} / \mathrm{Hf}$ & 31.9 & 28.8 & 28.9 & 31.1 & 25.8 & 26.1 & 31.6 & 25.2 & 27.3 & 27.8 \\
\hline $\mathrm{A} / \mathrm{CNK}$ & 1.00 & 1.03 & 1.01 & 1.01 & 1.02 & 1.03 & 0.97 & 1.05 & 1.06 & 1.04 \\
\hline $\mathrm{TFeO} / \mathrm{MgO}$ & 3.2 & 6.3 & 4.4 & 10.4 & 22.4 & 4.8 & 3.3 & 3.1 & 4.7 & 5.3 \\
\hline
\end{tabular}


Appendix 2 Continued.

\begin{tabular}{|c|c|c|c|c|c|c|c|c|c|}
\hline \multirow{2}{*}{$\begin{array}{l}\text { Location } \\
\text { Sample No. }\end{array}$} & \multicolumn{2}{|c|}{ Hirase } & \multicolumn{5}{|c|}{ Mihoro } & \multicolumn{2}{|c|}{ Fukushima dani } \\
\hline & 67RS-79 & $67 \mathrm{RS}-122$ & $66 \mathrm{RS}-6$ & $67 \mathrm{RS}-68$ & 67RS-69 & $67 \mathrm{RS}-70$ & $67 \mathrm{RS}-73$ & $67 \mathrm{RS}-58$ & $67 \mathrm{RS}-61$ \\
\hline $\mathrm{SiO}_{2}(\%)$ & 74.47 & 74.73 & 69.56 & 68.04 & 69.71 & 69.31 & 69.49 & 74.15 & 76.36 \\
\hline $\mathrm{TiO}_{2}$ & 0.16 & 0.15 & 0.43 & 0.49 & 0.41 & 0.43 & 0.40 & 0.20 & 0.08 \\
\hline $\mathrm{Al}_{2} \mathrm{O}_{3}$ & 13.15 & 13.11 & 15.07 & 15.39 & 15.04 & 15.14 & 15.06 & 13.62 & 12.45 \\
\hline $\mathrm{TFe}_{2} \mathrm{O}_{3}$ & 1.55 & 1.37 & 3.20 & 3.55 & 3.01 & 3.19 & 2.94 & 1.84 & 1.01 \\
\hline $\mathrm{MnO}$ & 0.05 & 0.05 & 0.09 & 0.10 & 0.09 & 0.09 & 0.08 & 0.06 & 0.03 \\
\hline $\mathrm{MgO}$ & 0.33 & 0.30 & 0.96 & 1.11 & 0.87 & 0.94 & 0.85 & 0.44 & 0.05 \\
\hline $\mathrm{CaO}$ & 1.14 & 0.95 & 2.37 & 3.00 & 2.52 & 2.61 & 2.50 & 1.19 & 0.34 \\
\hline $\mathrm{Na}_{2} \mathrm{O}$ & 3.75 & 3.82 & 4.46 & 4.49 & 4.69 & 4.73 & 4.70 & 3.98 & 2.66 \\
\hline $\mathrm{K}_{2} \mathrm{O}$ & 4.13 & 4.37 & 3.16 & 3.02 & 3.12 & 3.09 & 3.14 & 4.18 & 6.24 \\
\hline $\mathrm{P}_{2} \mathrm{O}_{5}$ & 0.05 & 0.04 & 0.11 & 0.14 & 0.12 & 0.12 & 0.11 & 0.05 & 0.01 \\
\hline LOI & 0.68 & 0.64 & 0.62 & 0.59 & 0.60 & 0.38 & 0.73 & 0.49 & 0.39 \\
\hline Total & 99.46 & 99.53 & 100.03 & 99.92 & 100.18 & 100.03 & 100.00 & 100.20 & 99.61 \\
\hline$V(\mathrm{ppm})$ & 9 & 8 & 36 & 48 & 32 & 38 & 31 & 11 & 5 \\
\hline $\mathrm{Cr}_{\mathrm{r}}$ & 23 & 15 & 26 & 12 & 16 & 16 & 10 & $<4$ & 12 \\
\hline $\mathrm{Ni}$ & 5 & 4 & 6 & 5 & 5 & 6 & 3 & 4 & 7 \\
\hline $\mathrm{Zn}$ & 29 & 16 & 31 & 46 & 73 & 72 & 58 & 45 & 30 \\
\hline $\mathrm{Ga}(\mathrm{XRF})$ & 14 & 13 & 11 & 13 & 18 & 19 & 19 & 18 & 14 \\
\hline $\mathrm{Rb}$ (XRF) & 116 & 149 & 95 & 91 & 97 & 97 & 103 & 152 & 188 \\
\hline $\mathrm{Sr}(\mathrm{XRF})$ & 128 & 102 & 255 & 279 & 249 & 255 & 257 & 120 & 81 \\
\hline $\mathrm{Y}(\mathrm{XRF})$ & 26.4 & 24.3 & 28.3 & 23.8 & 28.2 & 29.1 & 26.0 & 33.6 & 21.6 \\
\hline $\mathrm{Zr}(\mathrm{XRF})$ & 113 & 109 & 210 & 208 & 200 & 198 & 186 & 136 & 103 \\
\hline $\mathrm{Nb}$ & 6 & 5 & 3 & 3 & 10 & 12 & 10 & 14 & 9 \\
\hline Sn & 0.9 & 1.5 & 3.0 & 2.2 & 1.3 & 1.8 & 1.4 & 2.4 & 1.4 \\
\hline $\mathrm{Cs}$ & 1.4 & 1.6 & 2.4 & 2.0 & 1.1 & 2.1 & 1.9 & 2.7 & 2.3 \\
\hline $\mathrm{Ba} \quad(\mathrm{XRF})$ & 611 & 543 & 759 & 737 & 667 & 667 & 694 & 612 & 736 \\
\hline $\mathrm{La}$ & 29 & 26 & 42 & 36 & 35 & 37 & 31 & 32 & 28 \\
\hline $\mathrm{Ce}$ & 60 & 54 & 81 & 72 & 71 & 74 & 61 & 66 & 57 \\
\hline $\operatorname{Pr}$ & 6.9 & 6.1 & 9.7 & 8.8 & 8.2 & 8.5 & 7.3 & 7.6 & 6.5 \\
\hline $\mathrm{Nd}$ & 24 & 20 & 35 & 30 & 29 & 30 & 25 & 26 & 21 \\
\hline $\mathrm{Sm}$ & 5.0 & 4.8 & 6.0 & 5.7 & 4.6 & 5.1 & 4.3 & 4.2 & 3.3 \\
\hline Eu & 0.66 & 0.65 & 1.41 & 1.78 & 1.43 & 1.33 & 1.33 & 0.65 & 0.48 \\
\hline $\mathrm{Gd}$ & 4.6 & 4.2 & 5.2 & 5.6 & 4.8 & 4.8 & 4.1 & 4.4 & 3.0 \\
\hline $\mathrm{Tb}$ & 0.8 & 0.6 & 0.9 & 0.8 & 0.7 & 0.7 & 0.6 & 0.7 & 0.6 \\
\hline Dy & 4.2 & 3.1 & 4.7 & 4.4 & 3.9 & 4.3 & 3.8 & 4.4 & 2.6 \\
\hline Ho & 0.7 & 0.6 & 0.7 & 0.7 & 0.6 & 0.8 & 0.6 & 0.7 & 0.5 \\
\hline $\mathrm{Er}$ & 3.2 & 1.8 & 2.8 & 2.7 & 2.6 & 3.0 & 2.5 & 3.1 & 2.0 \\
\hline $\mathrm{Tm}$ & 0.4 & 0.4 & 0.4 & 0.4 & 0.5 & 0.6 & 0.4 & 0.6 & 0.5 \\
\hline $\mathrm{Yb}$ & 3.6 & 2.8 & 2.7 & 2.8 & 2.4 & 2.1 & 2.2 & 2.7 & 2.3 \\
\hline Lu & 0.5 & 0.4 & 0.5 & 0.4 & 0.4 & 0.4 & 0.3 & 0.5 & 0.4 \\
\hline $\mathrm{Hf}$ & 3.4 & 4.2 & 5.3 & 5.2 & 4.9 & 5.8 & 5.6 & 4.7 & 4.3 \\
\hline Ta & 0.6 & 0.5 & 0.3 & 0.3 & 0.8 & 0.9 & 0.8 & 1.2 & 1.3 \\
\hline $\mathrm{Pb}$ & 12 & 11 & 17 & 15 & 15 & 16 & 15 & 15 & 19 \\
\hline Th & 13.2 & 12.6 & 10.2 & 7.8 & 10.7 & 11.6 & 10.6 & 14.5 & 18.7 \\
\hline $\mathrm{U}$ & 3.0 & 3.3 & 1.7 & 1.5 & 2.2 & 2.3 & 2.3 & 2.8 & 3.3 \\
\hline REE & 169.8 & 149.4 & 220.6 & 194.8 & 192.6 & 201.6 & 169.8 & 186.2 & 150.1 \\
\hline $\mathrm{Sm} / \mathrm{Nd}$ & 0.21 & 0.24 & 0.17 & 0.19 & 0.16 & 0.17 & 0.17 & 0.16 & 0.15 \\
\hline $\mathrm{Rb} / \mathrm{Sr}$ & 0.9 & 1.5 & 0.4 & 0.3 & 0.4 & 0.4 & 0.4 & 1.3 & 2.3 \\
\hline $\mathrm{Th} / \mathrm{U}$ & 4.4 & 3.9 & 6.0 & 5.3 & 4.8 & 5.0 & 4.7 & 5.2 & 5.7 \\
\hline $10000 \mathrm{Ga} / \mathrm{Al}$ & 2.04 & 1.83 & 1.43 & 1.56 & 2.20 & 2.33 & 2.41 & 2.47 & 2.17 \\
\hline $\mathrm{Y} / \mathrm{Nb}$ & 4.5 & 5.4 & 8.8 & 8.4 & 2.7 & 2.5 & 2.6 & 2.4 & 2.4 \\
\hline $\mathrm{Nb} / \mathrm{Ta}$ & 9.5 & 9.6 & 9.7 & 10.4 & 13.5 & 13.7 & 13.0 & 11.3 & 7.2 \\
\hline $\mathrm{Zr} / \mathrm{Hf}$ & 33.1 & 25.8 & 39.9 & 39.9 & 40.5 & 34.1 & 33.5 & 29.2 & 24.0 \\
\hline $\mathrm{A} / \mathrm{CNK}$ & 1.03 & 1.03 & 1.00 & 0.96 & 0.96 & 0.95 & 0.96 & 1.03 & 1.06 \\
\hline $\mathrm{TFeO} / \mathrm{MgO}$ & 4.3 & 4.2 & 3.0 & 2.9 & 3.1 & 3.1 & 3.1 & 3.8 & 19.5 \\
\hline
\end{tabular}


Appendix 3 Major and trace element contents of the Toki, Naegi and Ryoke granitoids.

\begin{tabular}{|c|c|c|c|c|c|c|c|c|c|c|}
\hline \multirow[b]{2}{*}{ Element } & \multicolumn{7}{|c|}{ Toki } & \multirow[b]{2}{*}{$175 \mathrm{~A}$} & \multirow[b]{2}{*}{$175 \mathrm{~B}$} & \multirow[b]{2}{*}{213} \\
\hline & $\mathrm{T}-41$ & $\mathrm{~T}-38$ & $\mathrm{~T}-44$ & $\mathrm{~T}-51$ & $\mathrm{~T}-82$ & $\mathrm{~T}-25$ & $\mathrm{~T}-2$ & & & \\
\hline $\mathrm{SiO}_{2}(\%)$ & 68.10 & 70.57 & 72.72 & 74.44 & 74.29 & 75.18 & 75.54 & 76.52 & 76.88 & 76.74 \\
\hline $\mathrm{TiO}_{2}$ & 0.46 & 0.39 & 0.11 & 0.10 & 0.07 & 0.07 & 0.12 & 0.05 & 0.03 & 0.04 \\
\hline $\mathrm{Al}_{2} \mathrm{O}_{3}$ & 16.52 & 14.78 & 14.67 & 14.07 & 14.04 & 13.68 & 13.32 & 12.79 & 12.79 & 13.02 \\
\hline $\mathrm{Fe}_{2} \mathrm{O}_{3}$ & 0.64 & 0.40 & 0.56 & 0.40 & 0.24 & 0.16 & 0.32 & 1.27 & 1.28 & 1.07 \\
\hline $\mathrm{FeO}$ & 2.95 & 2.30 & 1.35 & 1.14 & 0.93 & 0.93 & 0.86 & & & \\
\hline $\mathrm{MnO}$ & 0.06 & 0.09 & 0.07 & 0.05 & 0.05 & 0.04 & 0.04 & 0.03 & 0.03 & 0.03 \\
\hline $\mathrm{MgO}$ & 0.96 & 0.77 & 0.21 & 0.24 & 0.11 & 0.08 & 0.14 & 0.03 & 0.03 & 0.05 \\
\hline $\mathrm{CaO}$ & 3.05 & 2.60 & 1.20 & 1.24 & 1.11 & 0.95 & 0.87 & 0.66 & 0.64 & 0.67 \\
\hline $\mathrm{Na}_{2} \mathrm{O}$ & 3.55 & 3.18 & 3.76 & 3.60 & 3.66 & 3.50 & 3.43 & 3.54 & 4.15 & 3.60 \\
\hline $\mathrm{K}_{2} \mathrm{O}$ & 3.05 & 3.57 & 4.63 & 4.28 & 4.77 & 4.85 & 4.31 & 4.88 & 4.11 & 4.84 \\
\hline $\mathrm{P}_{2} \mathrm{O}_{5}$ & 0.14 & 0.11 & 0.06 & 0.06 & 0.05 & 0.02 & 0.05 & $<0.01$ & $<0.01$ & $<0.01$ \\
\hline $\mathrm{H}_{2} \mathrm{O}^{+}$ & 0.54 & 0.70 & 0.63 & 0.21 & 0.38 & 0.50 & 0.31 & & & \\
\hline $\mathrm{H}_{2} \mathrm{O}^{-}$ & 0.22 & 0.20 & 0.26 & 0.38 & 0.28 & 0.14 & 0.32 & & & \\
\hline ILO & & & & & & & & 0.42 & 0.42 & 0.54 \\
\hline
\end{tabular}

\begin{tabular}{rrrrrrrrrrr} 
Total & 100.24 & 99.66 & 100.23 & 100.21 & 99.98 & 100.10 & 99.63 & 100.19 & 100.36 & 100.60 \\
\hline
\end{tabular}

\begin{tabular}{|c|c|c|c|c|c|c|c|c|c|c|}
\hline$V(\mathrm{ppm})$ & 51 & 44 & 5 & 6 & 3 & 4 & 8 & 3 & 1 & $<1$ \\
\hline $\mathrm{Cr}$ & 20 & 40 & 23 & $<4$ & $<4$ & 36 & 37 & $<4$ & $<4$ & $<4$ \\
\hline $\mathrm{Ni}$ & 8 & 6 & 10 & 7 & 5 & 13 & 14 & 8 & 14 & 7 \\
\hline $\mathrm{Zn}$ & 105 & 56 & 73 & 31 & 27 & 20 & 31 & 20 & 25 & 23 \\
\hline $\mathrm{Ga}$ & 22 & 19 & 21 & 19 & 21 & 21 & 18 & 21 & 26 & 20 \\
\hline $\mathrm{Rb}$ & 152 & 168 & 263 & 228 & 275 & 324 & 289 & 372 & 397 & 389 \\
\hline $\mathrm{Sr}$ & 342 & 259 & 108 & 83 & 64 & 48 & 41 & 16 & 2 & 14 \\
\hline $\mathrm{Y}$ & 24 & 24 & 42 & 56 & 54 & 74 & 85 & 82 & 206 & 76 \\
\hline $\mathrm{Zr}$ & 241 & 163 & 181 & 107 & 80 & 77 & 99 & 96 & 196 & 80 \\
\hline $\mathrm{Nb}$ & 9 & 8 & 13 & 11 & 10 & 14 & 17 & 15 & 38 & 14 \\
\hline Sn & 4.4 & 4.1 & 10.5 & 3.4 & 2.4 & 2.1 & 5.1 & 2.6 & 4.5 & 4.3 \\
\hline $\mathrm{Cs}$ & 5.0 & 4.9 & 13 & 6.3 & 5.7 & 5.1 & 8.6 & 8.6 & 9.4 & 11 \\
\hline $\mathrm{Ba}$ & 1206 & 704 & 757 & 259 & 215 & 178 & 112 & 60 & 2 & 29 \\
\hline $\mathrm{La}$ & 53 & 30 & 36 & 24 & 21 & 19 & 19 & 19 & 9 & 19 \\
\hline $\mathrm{Ce}$ & 101 & 60 & 72 & 51 & 47 & 40 & 37 & 44 & 22 & 43 \\
\hline $\operatorname{Pr}$ & 10.8 & 7.0 & 8.5 & 6.1 & 6.0 & 5.3 & 4.7 & 6.5 & 3.6 & 6.4 \\
\hline $\mathrm{Nd}$ & 39 & 26 & 30 & 22 & 22 & 20 & 18 & 24 & 17 & 25 \\
\hline Sm & 6.0 & 4.5 & 5.6 & 5.2 & 5.8 & 6.0 & 5.6 & 7.6 & 7.9 & 7.7 \\
\hline $\mathrm{Eu}$ & 1.43 & 0.96 & 0.97 & 0.45 & 0.43 & 0.25 & 0.36 & 0.09 & 0.01 & 0.14 \\
\hline Gd & 5.4 & 4.0 & 5.1 & 5.1 & 5.1 & 4.8 & 5.1 & 6.2 & 8.6 & 6.3 \\
\hline $\mathrm{Tb}$ & 0.7 & 0.6 & 1.0 & 1.2 & 1.1 & 1.4 & 1.4 & 1.6 & 2.7 & 1.8 \\
\hline Dy & 3.6 & 3.7 & 5.5 & 7.7 & 7.4 & 8.6 & 10.5 & 11.1 & 20.5 & 12.3 \\
\hline Ho & 0.6 & 0.6 & 1.1 & 1.4 & 1.4 & 1.7 & 2.0 & 2.0 & 4.0 & 2.1 \\
\hline Er & 2.2 & 2.2 & 4.2 & 5.5 & 5.2 & 6.1 & 8.2 & 6.6 & 15.3 & 5.7 \\
\hline $\mathrm{Tm}$ & 0.4 & 0.4 & 0.8 & 1.1 & 0.7 & 1.0 & 1.4 & 1.2 & 2.8 & 1.2 \\
\hline $\mathrm{Yb}$ & 2.3 & 2.4 & 4.6 & 5.9 & 5.7 & 8.6 & 11.5 & 8.5 & 20.4 & 8.0 \\
\hline $\mathrm{Lu}$ & 0.3 & 0.4 & 0.7 & 0.9 & 0.7 & 1.1 & 1.6 & 1.2 & 3.2 & 1.0 \\
\hline $\mathrm{Hf}$ & 5.5 & 4.3 & 4.7 & 3.5 & 2.7 & 3.2 & 4.0 & 3.8 & 9.1 & 3.7 \\
\hline $\mathrm{Ta}$ & 0.7 & 0.7 & 1.6 & 1.5 & 0.9 & 1.7 & 2.0 & 1.4 & 2.1 & 1.8 \\
\hline $\mathrm{Pb}$ & 14 & 20 & 46 & 28 & 31 & 30 & 36 & 30 & 40 & 31 \\
\hline $\mathrm{Th}$ & 17 & 17 & 25 & 25 & 27 & 24 & 26 & 40 & 74 & 33 \\
\hline$\underline{\mathrm{U}}$ & 4.1 & 4.0 & 3.2 & 3.3 & 5.2 & 7.0 & 10.3 & 17.1 & 10.6 & 13.6 \\
\hline REE & 253.18 & 168.89 & 216.84 & 196.01 & 183.88 & 190.52 & 208.70 & 217.50 & 313.70 & 208.54 \\
\hline $\mathrm{Sm} / \mathrm{Nd}$ & 0.15 & 0.18 & 0.19 & 0.23 & 0.27 & 0.30 & 0.31 & 0.31 & 0.47 & 0.31 \\
\hline $\mathrm{Rb} / \mathrm{Sr}$ & 0.41 & 0.61 & 2.22 & 2.53 & 3.73 & 6.00 & 6.02 & 18.88 & 84.50 & 20.87 \\
\hline $\mathrm{Th} / \mathrm{U}$ & 4.10 & 4.41 & 7.88 & 7.47 & 5.28 & 3.40 & 2.49 & 2.35 & 6.96 & 2.44 \\
\hline $10000 \mathrm{Ga} / \mathrm{Al}$ & 2.49 & 2.40 & 2.72 & 2.49 & 2.77 & 2.83 & 2.55 & 3.11 & 3.79 & 2.97 \\
\hline $\mathrm{Y} / \mathrm{Nb}$ & 2.77 & 3.29 & 3.05 & 5.44 & 5.22 & 4.79 & 4.90 & 5.05 & 4.63 & 4.85 \\
\hline $\mathrm{Nb} / \mathrm{Ta}$ & 12.04 & 10.83 & 8.46 & 7.17 & 11.00 & 8.24 & 8.24 & 10.55 & 18.11 & 8.03 \\
\hline $\mathrm{Zr} / \mathrm{Hf}$ & 41.39 & 29.59 & 38.33 & 29.08 & 30.27 & 27.18 & 24.01 & 21.90 & 18.82 & 19.94 \\
\hline $\mathrm{A} / \mathrm{CNK}$ & 1.12 & 1.07 & 1.10 & 1.10 & 1.02 & 1.07 & 1.12 & 1.04 & 1.03 & 1.05 \\
\hline $\mathrm{TFeO} / \mathrm{MgO}$ & 3.68 & 3.46 & 8.85 & 6.27 & 10.44 & 13.44 & 8.22 & 34.99 & 0.69 & 19.07 \\
\hline
\end{tabular}


Genesis of Late Cretaceous-Paleogene Granitoids (ISHIHARA and WU)

Appendix 3 Continued.

\begin{tabular}{|c|c|c|c|c|c|c|c|c|c|c|}
\hline \multirow[b]{2}{*}{ Element } & \multicolumn{6}{|l|}{ Naegi } & \multirow[b]{2}{*}{ T-139 } & \multirow[b]{2}{*}{$\mathrm{T}-97$} & \multirow[b]{2}{*}{$\mathrm{T}-105$} & \multirow[b]{2}{*}{$\mathrm{T}-110$} \\
\hline & 211 & 70 N505 & $70 \mathrm{~N} 506$ & $70 \mathrm{~N} 508$ & 70 N509 & $70 \mathrm{~N} 510$ & & & & \\
\hline $\mathrm{SiO}_{2}(\%)$ & 77.38 & 76.74 & 77.15 & 76.64 & 76.02 & 76.20 & 65.53 & 68.06 & 70.03 & 72.10 \\
\hline $\mathrm{TiO}_{2}$ & 0.05 & 0.03 & 0.04 & 0.11 & 0.05 & 0.05 & 0.55 & 0.52 & 0.29 & 0.24 \\
\hline $\mathrm{Al}_{2} \mathrm{O}_{3}$ & 12.67 & 12.65 & 12.40 & 12.49 & 12.61 & 12.69 & 16.60 & 14.96 & 14.83 & 14.36 \\
\hline $\mathrm{Fe}_{2} \mathrm{O}_{3}$ & 0.98 & 0.90 & 1.01 & 1.46 & 1.05 & 1.13 & 0.60 & 0.60 & 0.40 & 0.48 \\
\hline $\mathrm{FeO}$ & & & & & & & 3.84 & 3.20 & 2.14 & 1.58 \\
\hline $\mathrm{MnO}$ & 0.02 & 0.02 & 0.03 & 0.03 & 0.03 & 0.03 & 0.07 & 0.11 & 0.07 & 0.04 \\
\hline $\mathrm{MgO}$ & 0.04 & 0.04 & 0.06 & 0.09 & 0.00 & 0.01 & 1.30 & 1.45 & 0.70 & 0.47 \\
\hline $\mathrm{CaO}$ & 0.61 & 0.60 & 0.72 & 1.15 & 0.69 & 0.70 & 4.03 & 3.71 & 2.29 & 2.20 \\
\hline $\mathrm{Na}_{2} \mathrm{O}$ & 3.76 & 3.34 & 3.36 & 3.31 & 3.63 & 3.58 & 3.15 & 2.84 & 3.05 & 3.46 \\
\hline $\mathrm{K}_{2} \mathrm{O}$ & 4.54 & 5.07 & 4.72 & 4.25 & 4.78 & 4.85 & 2.78 & 3.10 & 5.10 & 3.82 \\
\hline $\mathrm{P}_{2} \mathrm{O}_{5}$ & $<0.01$ & $<0.01$ & $<0.01$ & 0.01 & $<0.01$ & $<0.01$ & 0.13 & 0.12 & 0.09 & 0.07 \\
\hline $\mathrm{H}_{2} \mathrm{O}^{+}$ & & & & & & & 0.82 & 0.67 & 0.48 & 0.57 \\
\hline $\mathrm{H}_{2} \mathrm{O}^{-}$ & & & & & & & 0.32 & 0.38 & 0.36 & 0.32 \\
\hline ILO & 0.76 & 0.54 & 0.38 & 0.44 & 0.40 & 0.41 & & & & \\
\hline Total & 100.81 & 99.93 & 99.87 & 99.98 & 99.26 & 99.65 & 99.72 & 99.72 & 99.83 & 99.71 \\
\hline $\mathrm{V}(\mathrm{ppm})$ & 1 & $<1$ & $<1$ & 4 & 2 & $<1$ & 22 & 36 & 27 & 10 \\
\hline $\mathrm{Cr}$ & $<4$ & $<4$ & $<4$ & $<4$ & $<4$ & $<4$ & $<4$ & 7 & $<4$ & $<4$ \\
\hline $\mathrm{Ni}$ & 9 & 11 & 6 & 4 & 8 & 8 & 6 & 5 & 6 & 2 \\
\hline $\mathrm{Zn}_{\mathrm{n}}$ & 22 & 23 & 20 & 21 & 19 & 19 & 45 & 53 & 47 & 42 \\
\hline $\mathrm{Ga}$ & 19 & 20 & 19 & 18 & 20 & 20 & 18 & 17 & 18 & 20 \\
\hline $\mathrm{Rb}$ & 394 & 375 & 307 & 221 & 331 & 326 & 166 & 136 & 221 & 161 \\
\hline $\mathrm{Sr}$ & 6 & 12 & 22 & 70 & 13 & 17 & 150 & 212 & 185 & 186 \\
\hline$Y$ & 95 & 127 & 68 & 52 & 100 & 93 & 43 & 35 & 36 & 35 \\
\hline $\mathrm{Zr}$ & 77 & 96 & 108 & 98 & 92 & 86 & 135 & 145 & 148 & 133 \\
\hline $\mathrm{Nb}$ & 12 & 17 & 12 & 12 & 13 & 16 & 7 & 7 & 8 & 8 \\
\hline Sn & 3.7 & 3.3 & 2.6 & 1.7 & 2.7 & 1.1 & 2.7 & 3.2 & 2.8 & 1.9 \\
\hline $\mathrm{Cs}$ & 12 & 7.2 & 9.1 & 4.4 & 9.4 & 5.3 & 5.5 & 4.9 & 4.0 & 4.1 \\
\hline $\mathrm{Ba}$ & 8 & 40 & 60 & 331 & 29 & 58 & 219 & 426 & 937 & 617 \\
\hline $\mathrm{La}$ & 16 & 22 & 23 & 34 & 26 & 23 & 25 & 28 & 19 & 39 \\
\hline $\mathrm{Ce}$ & 44 & 48 & 54 & 72 & 55 & 56 & 44 & 56 & 41 & 78 \\
\hline $\operatorname{Pr}$ & 7.0 & 7.4 & 6.9 & 8.7 & 8.3 & 7.1 & 6.2 & 6.9 & 5.0 & 9.3 \\
\hline $\mathrm{Nd}$ & 28 & 30 & 28 & 33 & 33 & 29 & 22 & 24 & 19 & 32 \\
\hline $\mathrm{Sm}$ & 9.2 & 9.8 & 6.9 & 7.3 & 9.8 & 7.3 & 4.8 & 4.7 & 3.7 & 6.8 \\
\hline Eu & 0.05 & 0.08 & 0.20 & 0.36 & 0.07 & 0.11 & 0.68 & 0.96 & 1.03 & 0.86 \\
\hline $\mathrm{Gd}$ & 8.4 & 9.0 & 6.3 & 5.5 & 8.2 & 7.1 & 4.0 & 4.2 & 3.8 & 4.7 \\
\hline $\mathrm{Tb}$ & 2.4 & 2.4 & 1.6 & 1.3 & 2.4 & 1.9 & 0.9 & 0.9 & 0.9 & 1.0 \\
\hline Dy & 15.9 & 16.9 & 10.1 & 8.5 & 14.6 & 12.5 & 5.9 & 5.4 & 5.5 & 4.9 \\
\hline $\mathrm{Ho}$ & 2.6 & 3.5 & 1.8 & 1.4 & 2.7 & 2.4 & 1.2 & 0.9 & 1.0 & 0.9 \\
\hline $\mathrm{Er}$ & 8.2 & 9.8 & 6.0 & 4.8 & 8.9 & 8.4 & 3.4 & 2.9 & 3.2 & 3.3 \\
\hline $\mathrm{Tm}$ & 1.4 & 2.0 & 1.1 & 0.9 & 1.6 & 1.4 & 0.7 & 0.6 & 0.5 & 0.4 \\
\hline $\mathrm{Yb}$ & 8.9 & 12.0 & 7.8 & 5.6 & 10.4 & 9.5 & 5.1 & 5.0 & 4.7 & 2.8 \\
\hline $\mathrm{Lu}$ & 1.2 & 1.6 & 1.0 & 0.7 & 1.3 & 1.1 & 0.6 & 0.6 & 0.6 & 0.4 \\
\hline $\mathrm{Hf}$ & 3.1 & 4.3 & 4.3 & 3.7 & 4.6 & 3.9 & 3.8 & 4.7 & 4.1 & 3.6 \\
\hline $\mathrm{Ta}$ & 1.5 & 2.0 & 1.4 & 1.2 & 1.6 & 1.8 & 0.9 & 1.1 & 1.2 & 0.7 \\
\hline $\mathrm{Pb}$ & 32 & 32 & 27 & 21 & 28 & 29 & 21 & 22 & 29 & 21 \\
\hline Th & 44 & 22 & 33 & 21 & 32 & 31 & 16 & 15 & 13 & 16 \\
\hline$\underline{\mathrm{U}}$ & 7.0 & 10.1 & 6.4 & 4.7 & 6.4 & 7.3 & 5.4 & 4.2 & 3.3 & 1.8 \\
\hline REE & 237.48 & 285.28 & 214.11 & 231.35 & 275.02 & 254.02 & 165.54 & 176.59 & 145.22 & 215.88 \\
\hline $\mathrm{Sm} / \mathrm{Nd}$ & 0.33 & 0.33 & 0.24 & 0.22 & 0.30 & 0.25 & 0.22 & 0.20 & 0.2 & 0.21 \\
\hline $\mathrm{Rb} / \mathrm{Sr}$ & 40.50 & 24.68 & 11.48 & 2.73 & 19.20 & 15.16 & 1.03 & 0.63 & 1.11 & 0.80 \\
\hline $\mathrm{Th} / \mathrm{U}$ & 6.29 & 2.23 & 5.11 & 4.49 & 5.08 & 4.25 & 2.95 & 3.70 & 3.82 & 9.14 \\
\hline $10000 \mathrm{Ga} / \mathrm{Al}$ & 2.82 & 2.98 & 2.87 & 2.78 & 3.00 & 3.02 & 2.07 & 2.14 & 2.23 & 2.69 \\
\hline $\mathrm{Y} / \mathrm{Nb}$ & 7.05 & 6.47 & 4.95 & 4.01 & 6.99 & 5.56 & 5.70 & 4.86 & 4.48 & 3.79 \\
\hline $\mathrm{Nb} / \mathrm{Ta}$ & 7.80 & 8.44 & 8.82 & 9.47 & 8.39 & 8.90 & 8.05 & 6.98 & 6.9 & 11.70 \\
\hline $\mathrm{Zr} / \mathrm{Hf}$ & 26.63 & 18.56 & 21.61 & 27.83 & 19.00 & 22.04 & 34.00 & 26.45 & 28.6 & 30.68 \\
\hline $\mathrm{A} / \mathrm{CNK}$ & 1.04 & 1.05 & 1.04 & 1.03 & 1.02 & 1.02 & 1.03 & 1.00 & 0.97 & 1.04 \\
\hline $\mathrm{TFeO} / \mathrm{MgO}$ & 22.27 & 23.38 & 15.56 & 15.43 & none & 102.70 & 3.37 & 2.58 & 3.58 & 4.29 \\
\hline
\end{tabular}


Appendix 3 Continued.

\begin{tabular}{lrrrrrr}
\hline & \multicolumn{3}{c}{ Ryoke Belt } & & & \\
Element & \multicolumn{1}{c}{-109 } & \multicolumn{1}{c}{$\mathrm{T}-114$} & $\mathrm{~T}-94$ & $\mathrm{~T}-60$ & $\mathrm{~T}-145$ & $\mathrm{~T}-70$ \\
\hline $\mathrm{SiO}_{2}(\%)$ & 73.04 & 72.67 & 73.42 & 76.17 & 74.54 & 74.96 \\
$\mathrm{TiO}_{2}$ & 0.15 & 0.14 & 0.26 & 0.10 & 0.14 & 0.12 \\
$\mathrm{Al}_{2} \mathrm{O}_{3}$ & 15.28 & 14.94 & 13.66 & 13.06 & 14.06 & 13.92 \\
$\mathrm{Fe}_{2} \mathrm{O}_{3}$ & 0.32 & 0.40 & 0.60 & 0.16 & 0.28 & 0.36 \\
$\mathrm{FeO}$ & 1.15 & 1.15 & 1.62 & 0.86 & 1.04 & 0.83 \\
$\mathrm{MnO}$ & 0.06 & 0.04 & 0.07 & 0.02 & 0.08 & 0.07 \\
$\mathrm{MgO}$ & 0.26 & 0.19 & 0.51 & 0.06 & 0.29 & 0.27 \\
$\mathrm{CaO}$ & 1.93 & 1.82 & 1.53 & 1.09 & 1.12 & 1.22 \\
$\mathrm{Na}_{2} \mathrm{O}$ & 3.01 & 3.05 & 3.14 & 3.29 & 3.29 & 2.93 \\
$\mathrm{~K}_{2} \mathrm{O}$ & 4.02 & 4.35 & 4.22 & 4.49 & 4.16 & 4.50 \\
$\mathrm{P}_{2} \mathrm{O}_{5}$ & 0.04 & 0.03 & 0.09 & 0.02 & 0.04 & 0.03 \\
$\mathrm{H}_{2} \mathrm{O}^{+}$ & 0.27 & 0.57 & 0.52 & 0.32 & 0.45 & 0.38 \\
$\mathrm{H}_{2} \mathrm{O}^{-}$ & 0.26 & 0.42 & 0.16 & 0.20 & 0.34 & 0.24 \\
$\mathrm{ILO}^{-}$ & & & & & & \\
\hline Total & 99.79 & 99.77 & 99.80 & 99.84 & 99.83 & 99.83 \\
\hline
\end{tabular}

\begin{tabular}{|c|c|c|c|c|c|c|}
\hline V (ppm) & 4 & 3 & 11 & 2 & 6 & 3 \\
\hline $\mathrm{Cr}$ & $<4$ & $<4$ & $<4$ & $<4$ & $<4$ & 14 \\
\hline $\mathrm{Ni}$ & 4 & 2 & 5 & 9 & 4 & 7 \\
\hline $\mathrm{Zn}$ & 20 & 27 & 38 & 29 & 32 & 33 \\
\hline $\mathrm{Ga}$ & 15 & 15 & 16 & 20 & 16 & 16 \\
\hline $\mathrm{Rb}$ & 195 & 136 & 209 & 240 & 263 & 294 \\
\hline $\mathrm{Sr}$ & 76 & 147 & 137 & 49 & 68 & 53 \\
\hline Y & 30 & 18 & 44 & 57 & 33 & 67 \\
\hline $\mathrm{Zr}$ & 63 & 72 & 132 & 91 & 68 & 64 \\
\hline $\mathrm{Nb}$ & 5 & 5 & 11 & 11 & 6 & 8 \\
\hline Sn & 1.3 & 1.0 & 4.1 & 1.6 & 5.5 & 4.2 \\
\hline $\mathrm{Cs}$ & 2.7 & 2.6 & 5.2 & 4.1 & 9.9 & 7.4 \\
\hline $\mathrm{Ba}$ & 416 & 812 & 453 & 253 & 232 & 93 \\
\hline $\mathrm{La}$ & 12 & 36 & 32 & 31 & 15 & 26 \\
\hline $\mathrm{Ce}$ & 31 & 60 & 62 & 70 & 31 & 31 \\
\hline $\operatorname{Pr}$ & 3.0 & 8.7 & 7.5 & 9.1 & 3.8 & 7.7 \\
\hline Nd & 10 & 31 & 25 & 32 & 13 & 29 \\
\hline $\mathrm{Sm}$ & 2.6 & 4.8 & 5.4 & 8.0 & 2.7 & 7.7 \\
\hline $\mathrm{Eu}$ & 0.47 & 0.88 & 0.65 & 0.43 & 0.36 & 0.36 \\
\hline Gd & 2.3 & 4.1 & 4.1 & 6.1 & 2.9 & 5.7 \\
\hline $\mathrm{Tb}$ & 0.6 & 0.7 & 1.0 & 1.5 & 0.7 & 1.6 \\
\hline Dy & 3.4 & 2.9 & 5.5 & 7.9 & 3.8 & 8.9 \\
\hline Ho & 0.8 & 0.5 & 1.2 & 1.6 & 0.7 & 1.8 \\
\hline $\mathrm{Er}$ & 3.0 & 1.2 & 4.2 & 5.0 & 2.8 & 6.6 \\
\hline $\mathrm{Tm}$ & 0.6 & 0.2 & 0.7 & 0.8 & 0.4 & 1.1 \\
\hline $\mathrm{Yb}$ & 3.4 & 1.3 & 5.8 & 4.6 & 3.4 & 7.4 \\
\hline $\mathrm{Lu}$ & 0.4 & 0.2 & 0.7 & 0.6 & 0.6 & 1.1 \\
\hline Hf & 2.3 & 2.1 & 4.4 & 3.0 & 2.7 & 2.6 \\
\hline $\mathrm{Ta}$ & 1.0 & 0.3 & 1.1 & 1.0 & 1.1 & 1.6 \\
\hline $\mathrm{Pb}$ & 30 & 19 & 30 & 29 & 31 & 44 \\
\hline Th & 25 & 14 & 23 & 23 & 18 & 23 \\
\hline $\mathrm{U}$ & 4.4 & 1.9 & 3.6 & 3.5 & 6.9 & 6.9 \\
\hline REE & 102.02 & 168.32 & 198.11 & 231.59 & 110.76 & 196.10 \\
\hline $\mathrm{Sm} / \mathrm{Nd}$ & 0.25 & 0.15 & 0.22 & 0.25 & 0.20 & 0.27 \\
\hline $\mathrm{Rb} / \mathrm{Sr}$ & 2.34 & 0.82 & 1.37 & 4.44 & 3.33 & 5.04 \\
\hline $\mathrm{Th} / \mathrm{U}$ & 5.71 & 7.24 & 6.34 & 6.54 & 2.63 & 3.41 \\
\hline $10000 \mathrm{Ga} / \mathrm{Al}$ & 1.83 & 1.92 & 2.26 & 2.82 & 2.19 & 2.18 \\
\hline $\mathrm{Y} / \mathrm{Nb}$ & 5.87 & 3.38 & 3.80 & 4.68 & 4.88 & 7.36 \\
\hline $\mathrm{Nb} / \mathrm{Ta}$ & 4.71 & 13.55 & 10.28 & 11.90 & 5.64 & 5.16 \\
\hline $\mathrm{Zr} / \mathrm{Hf}$ & 28.66 & 40.27 & 27.28 & 34.64 & 25.20 & 20.52 \\
\hline $\mathrm{A} / \mathrm{CNK}$ & 1.21 & 1.16 & 1.09 & 1.06 & 1.14 & 1.10 \\
\hline $\mathrm{TFeO} / \mathrm{MgO}$ & 5.54 & 7.97 & 4.25 & 16.76 & 4.46 & 4.29 \\
\hline
\end{tabular}




\section{日本の中部地方の対照的に異る化学的性質を持つ白垔紀後期一古第三紀花崗岩類の成因}

\section{石原舜三・呉澄宇}

要旨

白亜紀後期－古第三紀の流紋岩類（11試料）と花崗岩類（白川 29, 土岐7, 苗木9, 領家 10 , 合計55試 料）について，XRF と ICP-MS 法により11主成分，32微量成分について分析した．白川地域の花崗 岩類は飛騨変成帯に貫入し，Iタイプ磁鉄釷系に属する花崗岩一花崗閃緑岩からなり，鳩ケ谷岩体北部 では苦鉄質アンクラーヴが優白質花崗岩に混在する，白川花崗岩類はハーカー図上で高ナトリウム組 （モンゾ閃緑岩一花崗閃緑岩）と低ナトリウム組（花崗岩）とに分けられる. 前者は同様な化学的特徴 を持つ, 現在の飛騨帯に見られるような苦鉄質火成岩起源の変成岩類や花崗岩類に由来するものと考之 られる。一方，花崗岩は八プロ花崗岩と呼べる珪長質度を持ち，その $\mathrm{Rb} / \mathrm{Sr}$ 比は分別残液に見られる 高い值を示さず，これは中性火成岩の部分溶融に由来するマグマの初期溶融相と判断される，共にY, HREEに乏しく，源物質に柘榴石などの存在が推察される。

山陽一領家帯の白亜紀後期一古第三紀の花崗岩類は美濃帯とその南方延長部の領家変成岩類に貫入す るIタイプチタン鉄鉱系であり, 山陽帯の土岐・苗木花崗岩では浅部相, 南部の領家花崗岩ではやや深 部相が産出している。これらはパーアルミナスかつチタン鉄鉱系である点で, 起源物質として $\mathrm{Al}, \mathrm{C}$ に富む堆積岩類との関連，更に角閃石含有相には火成岩起源が想定される。土岐・苗木花崗岩は親石元 素に富むが，苗木花崗岩では特に $\mathrm{Rb}, \mathrm{Y}, \mathrm{Th}, \mathrm{U}$ 扔よび $\mathrm{Rb} / \mathrm{Sr}$ が高い。その REE パターンは HREE に富むフラット型で著しい負の Eu 異常を示し，これが分化したIタイプマグマから固結したことを暗 示する. 